\title{
17. TERTIARY SEDIMENTS OF THE VØRING PLATEAU, NORWEGIAN SEA, RECOVERED BY LEG 38 OF THE DEEP SEA DRILLING PROJECT
}

\author{
Vivian N.D. Caston, British Petroleum Company Ltd., Britannic House, Moor Lane, London EC2Y 9BU
}

\begin{abstract}
Six holes were drilled on or adjacent to the V $\phi$ ring Plateau, Norwegian continental margin, during the course of DSDP Leg 38. Three were drilled within a sedimentary basin lying to landward of a prominent buried discontinuity, the V $\phi$ ring Plateau Escarpment; the others bottomed in basaltic basement to the northwest of this feature.

No sediments older than Tertiary were recovered. A virtually complete Tertiary succession through to the early Eocene was cored at Site 338 drilled on the outer plateau, but in the sedimentary basin the deepest hole penetrated only to the middle Miocene. However, within this basin, oozes of Eocene age were cored from the center of a diapir.

The cores recovered indicated that terrigenous sediments, in part derived from erosion of basaltic highs, were dominant on the outer part of the plateau during the early Eocene. These were succeeded in the late Eocene by pelagic siliceous sediments, which continued through the Pliocene. An increase in terrigenous sedimentation at this time marked the onset of glacial conditions, which were responsible for the deposition of poorly sorted muds and pebbly muds throughout the Plio-Quaternary.

Sediment deposition and facies variation indicate that basement highs to the northwest of the escarpment were being actively eroded until the end of the early Eocene and did not sink to a level at which sediment could accumulate until the early Miocene. Correlation of sedimentary data with seismic profiles in this area suggests that the escarpment is a major fault that has been active throughout the Tertiary and probably the Quaternary. Clay diapirism in the basin is a recent phenomenon related to the creation of a density imbalance by deposition of terrigenous sediments in the Plio-Pleistocene.
\end{abstract}

\section{INTRODUCTION}

The Norwegian continental margin, in particular the V $\phi$ ring Plateau area, has attracted considerable scientific attention for over a decade. A comprehensive structural synthesis based upon geophysical data has been published by Talwani and Eldholm (1972) and recently extended for the entire Norwegian-Greenland Sea (Talwani and Eldholm, in press). This and other data in the context of Leg 38 results are reviewed by Talwani and Udintsev (this volume).

The V $\phi$ ring Plateau is approximately triangular in plan and lies between $65^{\circ}$ and $68^{\circ} 30^{\prime} \mathrm{N}$ partway down the Norwegian continental slope at an average depth of approximately 1450 meters. The relatively straight and abrupt southwestern margin is formed by the JanMayen Fracture Zone. Geophysical studies have shown that the plateau is effectively divided into two parts by a prominent buried discontinuity (the V $\phi$ ring Plateau Escarpment), which trends in a northeasterly direction across the outer part of the plateau (Figure 1). Northwest of the escarpment, acoustic basement generally lies less than $1 \mathrm{~km}$ below the sea bed, whereas to the southeast, reflection and refraction results in- dicate the presence of a basin with up to $8 \mathrm{~km}$ of sediments of possibly Paleozoic to Tertiary age (Talwani and Eldholm, 1972). The indications to date (see below) are that the escarpment marks the line of a major fault. From indirect evidence, Hinz (1972) considers that the downthrown sedimentary basin to the southeast is a rift zone or graben, although the complementary bounding fault or faults to landward have not been mapped. The basement high or ridge lying to seaward of the escarpment has been the subject of controversy, being interpreted as oceanic crust (Talwani and Eldholm, 1972), or a continental fragment (Hinz, 1972).

Despite this interest, surprisingly little attention has been paid to the nature of the sediments on the floor of the Norwegian-Greenland Sea. In the area of the V $\phi \mathrm{r}$ ing Plateau, the only information available prior to Leg 38 was a record of Paleocene volcanic lutites recovered below $60 \mathrm{~cm}$ of Quaternary sandy muds in a $332-\mathrm{cm}-$ long core at $66^{\circ} 21^{\prime} \mathrm{N}, 00^{\circ} 18^{\prime} \mathrm{E}$ (Saito et al., 1967), and the presence of Eocene diatomites on a diapiric structure at $67^{\circ} 12^{\prime} \mathrm{N} 06^{\circ} 10^{\prime} \mathrm{E}$ (Bjorklund and Kellogg, 1972). A review of sediment distribution in the entire Norwegian-Greenland Sea by Eldholm and Windisch 


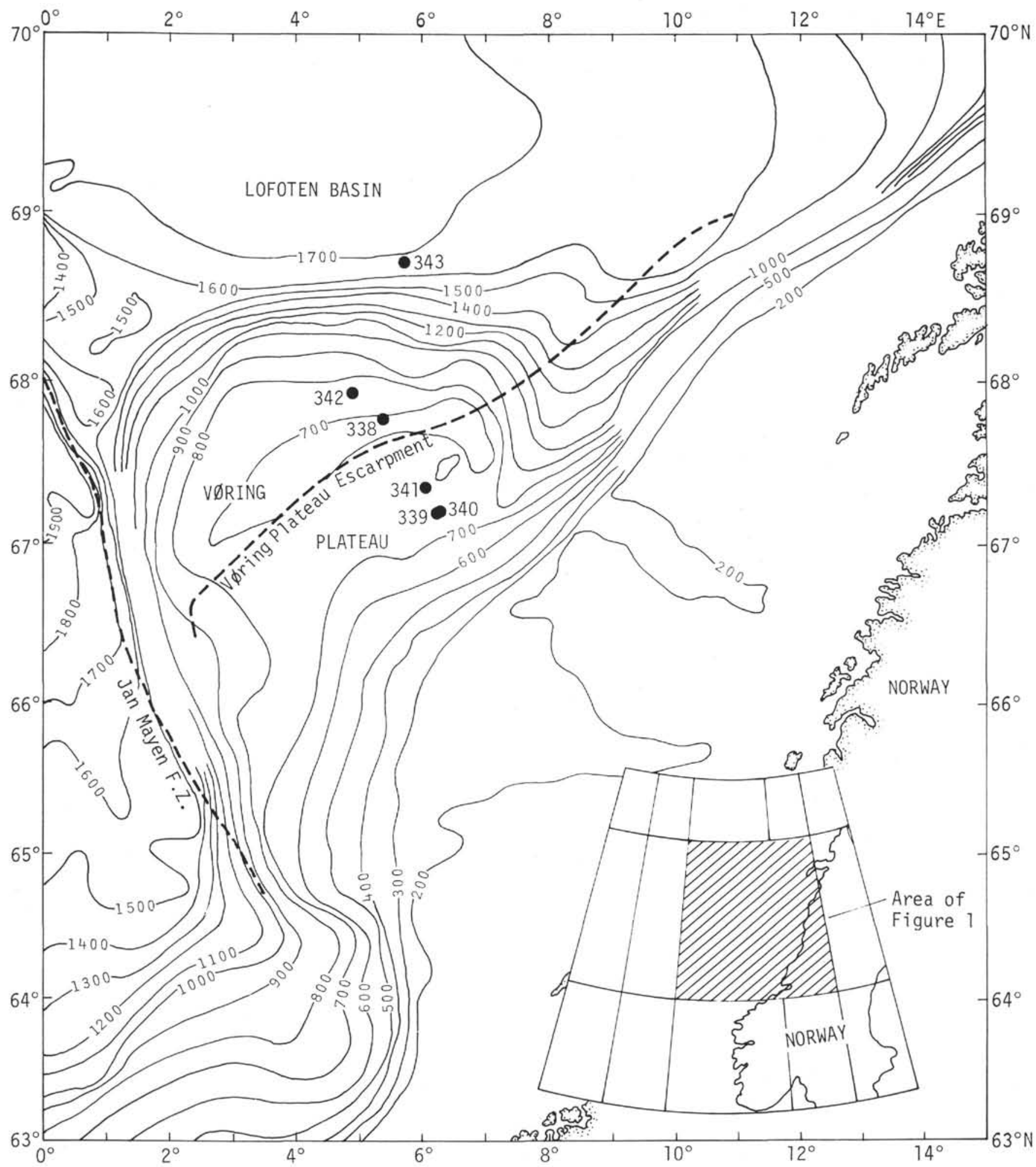

Figure 1. Location of Voring Plateau, approximate bathymetry (in nominal fathoms) and positions of Jan-Mayen Fracture Zone, Voring Plateau Escarpment, and DSDP Sites 338-343 (after Talwani and Eldholm, 1972). 
TABLE 1

Leg 38 Holes Drilled on or Adjacent to the Vøring Plateau

\begin{tabular}{lcccc}
\hline Site & Latitude & Longitude & $\begin{array}{c}\text { Water } \\
\text { Depth } \\
(\mathrm{m})\end{array}$ & $\begin{array}{c}\text { Penetration } \\
\text { Subsea Bed }(\mathrm{m})\end{array}$ \\
\hline 338 & $67^{\circ} 47.11^{\prime} \mathrm{N}$ & $05^{\circ} 23.26^{\prime} \mathrm{E}$ & 1315.0 & 437.0 \\
339 & $67^{\circ} 12.65^{\prime} \mathrm{N}$ & $06^{\circ} 17.05^{\prime} \mathrm{E}$ & 1276.0 & 108.0 \\
340 & $67^{\circ} 12.47^{\prime} \mathrm{N}$ & $06^{\circ} 18.38^{\prime} \mathrm{E}$ & 1244.0 & 104.5 \\
341 & $67^{\circ} 20.10^{\prime} \mathrm{N}$ & $06^{\circ} 06.64^{\prime} \mathrm{E}$ & 1443.5 & 456.0 \\
342 & $67^{\circ} 57.04^{\prime} \mathrm{N}$ & $04^{\circ} 56.02^{\prime} \mathrm{E}$ & 1316.0 & 170.5 \\
343 & $68^{\circ} 42.91^{\prime} \mathrm{N}$ & $05^{\circ} 45.73^{\prime} \mathrm{E}$ & 3165.0 & 284.0 \\
\hline
\end{tabular}

(1974) concentrated almost exclusively upon sedimentary thicknesses and emphasized the need for geologic data in this area.

\section{DATA AND METHODS}

This paper is concerned solely with the Tertiary sediments of the V $\phi$ ring Plateau area and is based upon preliminary analyses of samples selected from Sites 338343 inclusive drilled during Leg 38 , together with selected reflection profile and refraction data obtained by Glomar Challenger and R.V. Vema of the LamontDoherty Geological Observatory. Site coordinates, water depths, and hole penetrations are summarized in Table 1 and their locations shown in Figure 1. Further details of each site are given in the relevant Site Report chapters (this volume). Three holes were drilled northwest of the escarpment and three in the sedimentary basin to the southeast. The positions of these sites are important in terms of the underlying crustal structure and are shown with reference to a seismic cross-section (Figure 2), which is oriented approximately north-south across the northern part of the plateau (Figure 3 ).

Smear slides were made from samples selected onboard ship. The majority of these were used for shipboard core descriptions, but all were subsequently reexamined by the author to provide a measure of continuity in this comparative study. All compositional percentages quoted are estimates made from these slides. Thin sections made from certain lithified core samples and selected unconsolidated sediments, using standard impregnation techniques, proved particularly useful in studying the composition of Eocene sands and sandy muds. Heavy mineral separations were also made from sandy muds, but available sample amounts were insufficient to permit quantitative estimates to be made. Xray diffraction analyses of the clay fraction were made routinely through major portions of all holes.

Grain-size analyses and percentage of calcium carbonate at intervals throughout the holes were provided by DSDP; some additional size analyses were undertaken to fill significant gaps in the coverage.

\section{TERTIARY LITHOLOGIES}

The sediments are discussed throughout with reference to a correlation diagram (Figure 4), in which they have been simplified into major facies units. This diagram shows also all core positions and hole depths sub-seabed, which will be referred to in the text.

\section{Eocene}

Sediments of Eocene age were recovered only from Sites 338,340 , and 343 . Of these, the mixed early to late Eocene diatomaceous oozes at Site 340, drilled from the center of a diapir, are not in situ, and are therefore unlikely to be fully representative of the complete Eocene succession within the V $\phi$ ring Plateau basin. On the seaward (west) side of the escarpment, Site 338 penetrated 136.2 meters of Eocene sediments ranging in age from early to late Eocene (43 to 52 m.y. nannofossils), although there are no identifiable midEocene deposits. Core recovery in the lowest 79 meters is poor (only $21 \%$ ), so descriptions of this interval must necessarily be generalized. At Site 343, 104.3 meters of Eocene sediments were penetrated, but here both the top of the Eocene and also the possible presence of younger sediments may be concealed within an uncored interval between 107.5 and 145.5 meters.

Despite these constraints, the cores recovered provide a valuable record of depositional environments on the continental margin at an early stage in the development of the Norwegian Sea.

At Sites 338 and 343 , the most significant feature is the dominantly terrigenous sediment recorded throughout the early Eocene, and its replacement by pelagic siliceous oozes during the middle Eocene (ca. 43-49 m.y.) at Site 343, and in the late Eocene (ca. 43 m.y.) at Site 338 . At Site 340 within the V $\phi$ ring Plateau basin, the oldest oozes are middle Eocene.

Early Eocene terrigenous sediments are coarser grained at Site 338. Cores 31 through 35 (Figure 5) consist of mud, locally sandy and/or calcareous, but below this the dominant lithology to the base of the unit at 400.85 meters is a brownish-gray sandy mud, locally micaceous, with a variable sand content. The four principal components of this sandy mud are quartz, clay minerals, lithic fragments, and opaque grains. The relative proportions of these change downhole, quartz and clay decreasing from values of ca. $50 \%$ and $30 \%$, respectively, in Cores 37 and 38 , to $25 \%-30 \%$ and $15 \%$ $20 \%$ in the cores immediately above basement. However, the content of lithic and opaque fragments increases proportionately to totals of ca. $30 \%$ and $15 \%$ $25 \%$, respectively, in Cores 41 and 42 . Lithic fragments consist largely of highly altered and calcitized finely vesicular trachytic lava, together with mudstone clasts. Mineral grains identified include green, slightly pleochroic amphibole, brown and green micas, altered feldspar, and volcanic glass fragments.

The corresponding sediments at Site 343 consist almost entirely of olive-black to dark greenish-gray mud and rare sandy mud. DSDP grain-size measurements show an average of $4.7 \%$ sand through Cores 7 to 11 , contrasting with an average of $15 \%$ in the Core 31 38 interval for Site 338 . Lying immediately above the top basalt horizon, the lower part of this early Eocene succession (Subunit 3B, see Site 343 Report, this volume) consists of a 1.2 meter thick horizon of thinbedded turbidites with complete and partial Bouma sequences. Some contain conglomeratic pebbles up to $2.5 \mathrm{~cm}$ in diameter, sand- and silt-size grains, most of which are composed of mudstone and/or decomposed 

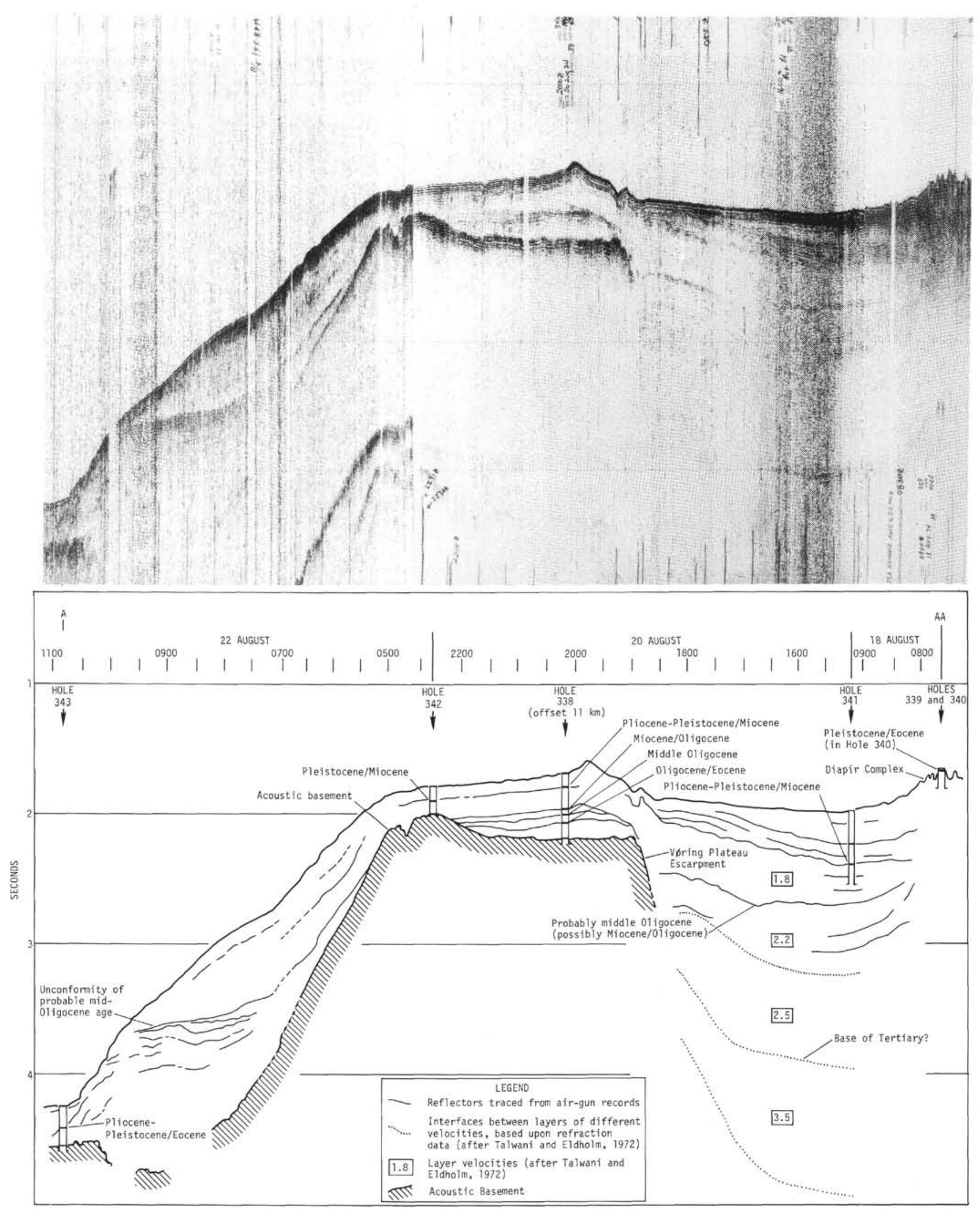

Figure 2. Composite airgun profile A-AA shot by Glomar Challenger between Sites 339/340 and 343. For track of profile see Figure 3. Also shown is a profile interpretation including site positions, significant reflectors, and basement surface (emphasized by oblique shading). Refraction data (layers shown by dotted lines, velocities given in boxes) taken from Talwani and Eldholm (1972) and plotted on the assumption that the base of the $1.8 \mathrm{~km} / \mathrm{sec}$ layer is equivalent to the midOligocene reflector (see text). 


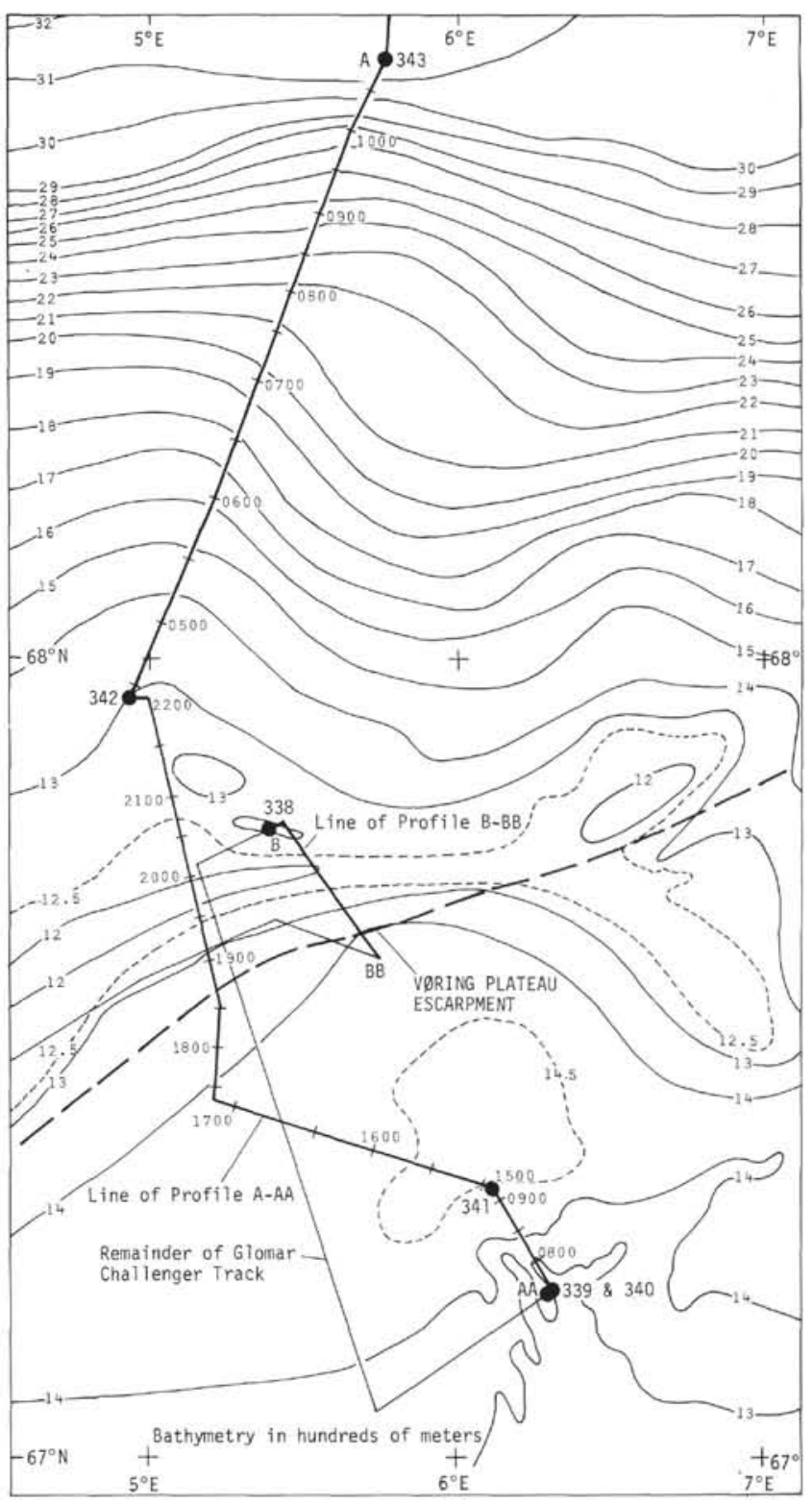

Figure 3. Detailed bathymetry of a part of the Vøring Plateau, showing positions of profiler sections $A-A A$ and $B-B B$ (Figures 2 and 9) together with DSDP drill sites.

basalt. Quartz and feldspar are present in quantities of less than $5 \%$, but glauconite is present locally in significant amounts ranging from $2 \%$ to $25 \%$.

The greater part of the mud in these lower cores consists of clay, of which illite is the dominant mineral (43\%-56\% in Cores 7 to 11 ), but with montmorillonite increasing abruptly to nearly $80 \%$ just above basement in Core 12 , Section 2, and remaining at a relatively high level throughout Unit 4 between the basalt horizons. Biogenic content is low, generally less than $7 \%$, but there is up to $30 \%$ calcite in the interbasaltic layer (Unit 4). This carbonate is mainly authigenic, but some fragments have a fibrous appearance suggesting possible derivation from shell material.

No terrigenous sediments of middle Eocene age have been recorded, although Cores 30 and 31 at Site 338 are undated and lie between early Eocene muds and late Eocene diatom oozes. This interval, which virtually corresponds to Subunit 3A (Site Report, this volume), consists of distinctive greenish-black glauconitic sandy mud and mud. It has an abrupt contact with the overlying diatom ooze, but appears to have a gradational lower boundary.

These sediments include rounded lithic grains, similar to those in the underlying muds, consisting either of mudstone or altered trachytic lava, together with grains of amphibole, pyroxene, magnetite, and subhedral plagioclase. These all suggest derivation from a dominantly basic igneous source. Quartz is rare. Glauconite grains are present up to $2.0 \mathrm{~mm}$ in diameter and are set in clay matrix, which increases in proportion below Core 30, Section 2. The glauconite appears to be replacing both microfossils and fecal pellets (White, this volume), and glauconite-coated volcanic glass shards are present throughout the unit. It is tempting to correlate this evidence of volcanism with the ash layers seen in Cores 7 and the upper part of Core 8 in Hole 343 (Figure 4), in which case the glauconitic sands would be of uppermost early Eocene age, but ash layers are also recorded within the middle Eocene age diatom oozes of Core 5 in the same hole, so the evidence is inconclusive. The extremely localized development of glauconite is, however, evidence of some significant variation in the depositional environment at this time.

A possible explanation is that the glauconitic sands represent early Eocene sediment partially reworked during a mid-Eocene hiatus. This would explain the concentration of lithic grains similar to those seen in the underlying muds, the occurrence of volcanic glass throughout the unit, and the growth of glauconite around suitable nuclei, together with the upward coarsening of the sediment in the two cores, and the absence of datable microfossils.

A major change in the sedimentation pattern is represented by the upper contact, at 285 meters, of this glauconitic sandy mud with the overlying pelagic diatom oozes of late Eocene age. These include a proportion of clay (dominantly montmorillonite) ranging from $10 \%$ to $20 \%$ in Core 29 to $30 \%$ in Core 26 . However, there appears to be a complete absence of lithic fragments and characteristic heavy minerals seen throughout the underlying terrigenous section.

This change to pelagic sedimentation (although here of middle Eocene age) is recorded equally abruptly at the Core $6 / 7$ boundary, at 202.5 meters, at Site 343 . However, poor recovery in Core 6 (Figure 5) may disguise the exact nature of the contact, and scarcity of samples prevents much of significance to be deduced from detailed analysis. The sequence consists essentially of muddy diatom ooze, locally calcareous, with $10 \%$ $25 \%$ clay and six volcanic ash horizons. As at Site 338, there appears to be a total absence of the lithic fragments and mica flakes seen in the early Eocene muds. The upper $70 \mathrm{~cm}$ or so of Core 5 consists of mud with individual sand laminae up to $3 \mathrm{~cm}$ thick in Core 5 , Section 1. The coring gap of 38 meters between Cores 4 and 5 unfortunately conceals the overall relationship of this influx of terrigenous material to the Eocene sedimentation pattern. Since sediments of this age are 


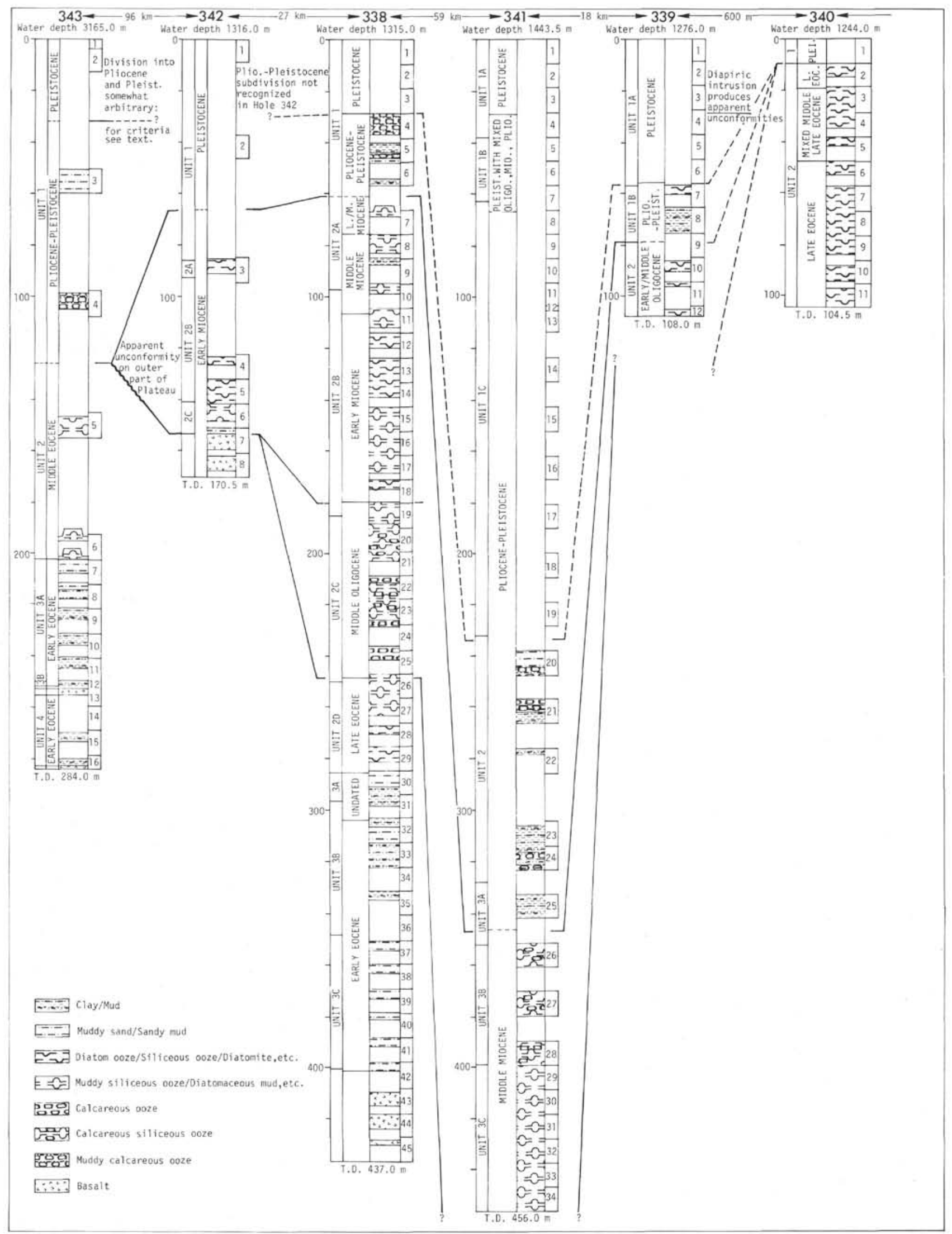

Figure 4. Facies correlation diagram for Sites 338-343 inclusive, showing distribution of principal sedimentary facies, lithologic units referred to in text, sediment ages (from micropaleontologic studies, see this volume), and core positions. Sediment shown only where core recovered. 
not recognizable at Site 338, no direct comparisons are possible.

At Site 340, the middle to late Eocene age oozes are almost entirely of pelagic origin with a lower proportion of terrigenous components than at either of the other two sites. A maximum of $15 \%$ clay is locally present within the slightly muddier oozes of Cores 4-7, which correspond approximately to those of mixed middle/late Eocene age. This perhaps reflects the higher proportion of terrigenous material seen in the middle Eocene oozes at Site 343, compared with those of late Eocene age at Site 338. Montmorillonite is the dominant clay mineral at all three sites.

\section{Oligocene}

In situ Oligocene sediments were only cored at Site 338. Site 339 penetrated directly from Pleistocene muds into Oligocene oozes, and mixed Oligocene to Pliocene age oozes are present within the Plio-Pleistocene sediments at Site 341, but both occurrences are attributable to diapirism, and therefore subject to the same qualification as the Eocene oozes at Site 340 .

At Site 338, 68.5 meters of middle Oligocene oozes immediately overlie those of late Eocene age described above and are part of a sequence that continues into the early Miocene. In neither case is there any sedimentary evidence of a hiatus in either the early or late Oligocene. This middle Oligocene succession, though almost entirely pelagic, differs markedly from the under- and overlying diatom oozes because of its dominantly calcareous composition. The calcareous incursion commences abruptly in Sample 25, CC (Figure 6), where the sediment is virtually a pure nannofossil ooze with over $90 \%$ calcium carbonate. This proportion then decreases progressively, though irregularly, to near zero at the top of the Oligocene sequence, with calcareous horizons alternating with diatom and muddy diatom oozes.

These alternations are shown graphically in Figure 6, which is a plot of the relative proportions of the principal sediment components based upon smear-slide estimates. It should be emphasized that the sample spacing is insufficient to demonstrate the finer detail present. From visual examination it is apparent that color stratification, representing interbedded nannofossil ooze, siliceous nannofossil ooze, calcareous diatom ooze, diatom ooze, muddy diatom ooze, and mud, is present particularly in Cores 23 to 25 . The layers range in thickness from a few centimeters to over a meter, commonly about $20 \mathrm{~cm}$. This is evidence of considerable fluctuations in the depositional environment in this area during the middle Oligocene.

Apart from the proportion of clay, which typically remains as a background $15 \%-20 \%$ throughout the dominantly pelagic horizons, but which locally increases to $80 \%$ in Core 24 , Section 5 , there are few other terrigenous components.

The lower part of the sequence, including Cores 24 and 25 , coincides with a distinct increase in sediment mean compressive strength and velocity (Site 338 Report, this volume). It is suggested that this increase may be related to diagenetic changes associated with the local predominance of calcareous ooze within an otherwise essentially siliceous or muddy siliceous sequence.

Oligocene sediments are not present at Site 342, and are either not present or not recorded at Site 343. Within the V $\phi$ ring Plateau basin, oozes of early/middle Oligocene age are present within a diapir cored at Site 339 and consist primarily of diatoms with subordinate quantities of other siliceous components and little terrigenous input. In Core 10, Section 1 and Core 11, Section 1, the composition is locally a diatomaceous mud, but the calcium carbonate content is negligible throughout the cored interval, contrasting markedly with that recorded at Site 338.

Mixed impure siliceous oozes, ranging from Oligocene to Pliocene in age, form a 25-meter-thick allochthonous subunit within the Pleistocene at Site 341. This has not been subdivided, so specific Oligocene age sediments cannot be compared with those in the other two holes. The oozes have, in general, a higher proportion of quartz and feldspar (up to $12 \%$, of which some $5 \%$ are sand-size) than the other oozes of this age, but this may have been caused by mixing with Pleistocene muds at the time of emplacement. The higher proportion of other siliceous components, with up to $20 \%$ Radiolaria and $30 \%$ sponge spicules, also differs from that observed at the other two sites, and is comparable rather with the siliceous component of Pliocene age sediments (see below).

\section{Miocene}

Sediments of Miocene age were cored at two sites drilled west of the V $\phi$ ring Plateau Escarpment, and one, Site 341 , east of the escarpment within the V $\phi$ ring Plateau basin. The sediments consist almost exclusively of pelagic siliceous oozes with varying proportions of clay and calcareous nannoplankton.

At Site 338, diatom oozes comprise the major proportion of Subunit 2B from ca. 92.5 to 141 meters (Figure 4) with subordinate layers of muddy diatom ooze, and a single calcareous diatom ooze in Core 15 , Section 4. Figure 7 shows that total pelagic siliceous content exceeds $70 \%$ through much of this interval, reaching $97 \%$ in some very pure oozes in Core 14 , Section 3. Apart from the clay content, terrigenous input is restricted to rare quartz and feldspar grains or mica flakes, although in Core 11, Section 4 there is $7 \%$ glauconite.

Total terrigenous content increases gradually up the sequence from a minimum in Core 14 , Section 3 to $30 \%$ in Core 10, Section 2, which has been selected as the base of Subunit 2A. This upper division, dating from middle to middle/late Miocene, appears to be intermediate in composition between the overlying muds and calcareous muds of Pliocene age and the underlying diatom ooze. The dominant lithology is an oliveblack to olive-gray muddy diatom ooze. This is distinguishable from the underlying diatom ooze, not only by a higher terrigenous content, but also by higher proportions (each up to $15 \%$ ) of both Radiolaria and sponge spicules.

$\mathrm{X}$-ray diffraction analyses (Figure 7) show a gradual increase upwards in illite content from $20 \%$ in Core 17 to near $60 \%$ in Core 13, Section 3, followed by a 
HOLE 343

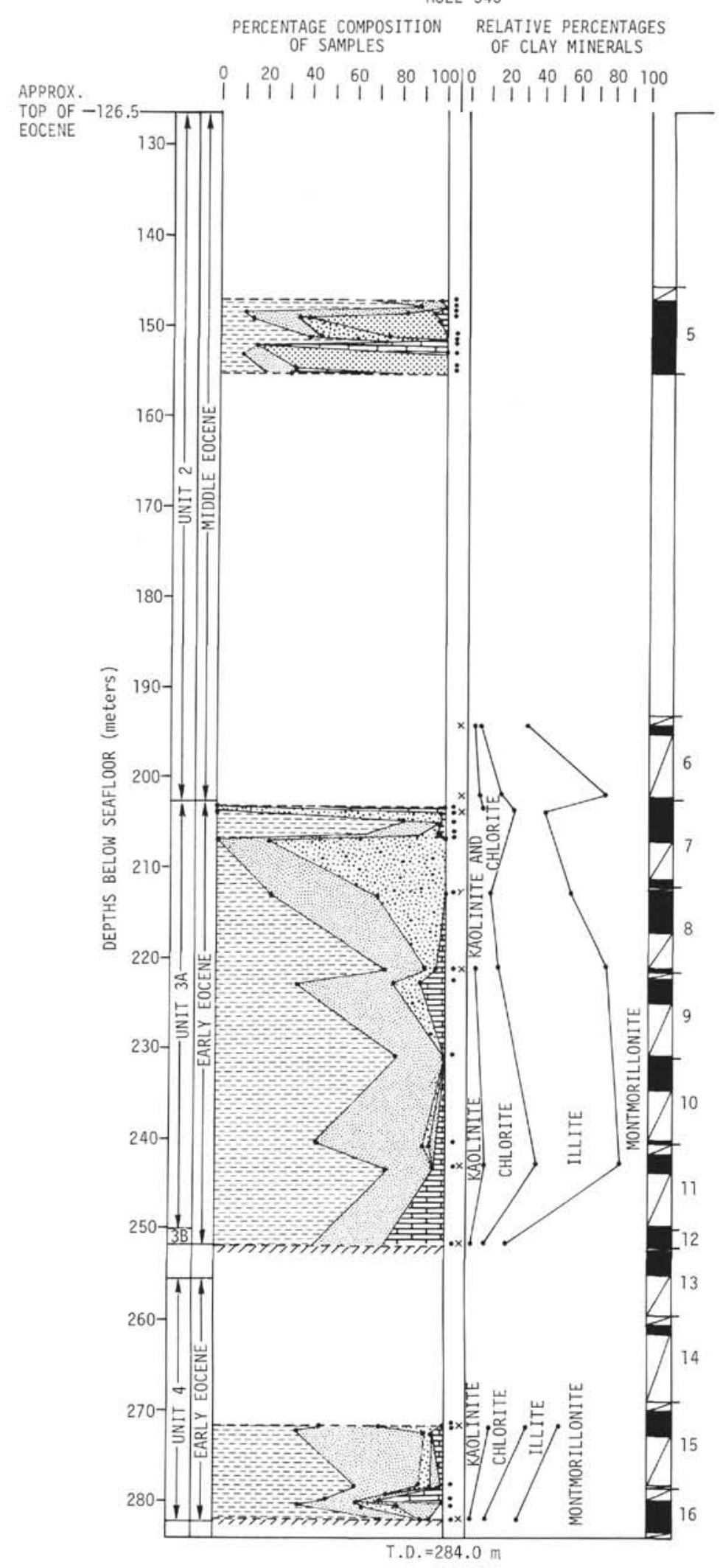

Figure 5. Compositional facies diagram for the Eocene at Sites 338, 340, and 343. This shows lithologic units referred to in text, ages (on micropaleontologic evidence), core positions (including those parts of core recovered), lithologic and $X$-ray sample positions, percentage composition of lithologic samples (smear-slide estimates), and relative proportions of the clay mineral fraction (X-ray diffraction analyses). 
HOLE 338

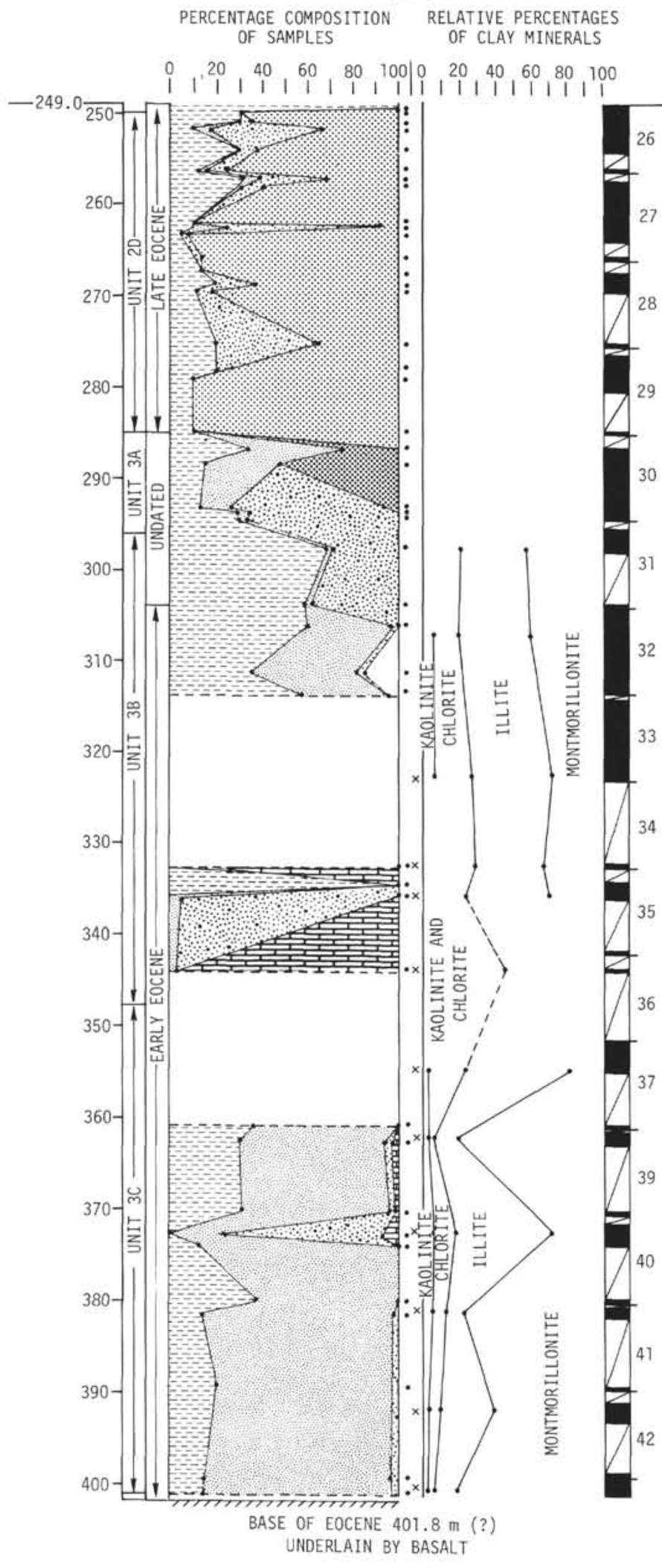

HOLE 340

PERCENTAGE COMPOSITION OF SAMPLES

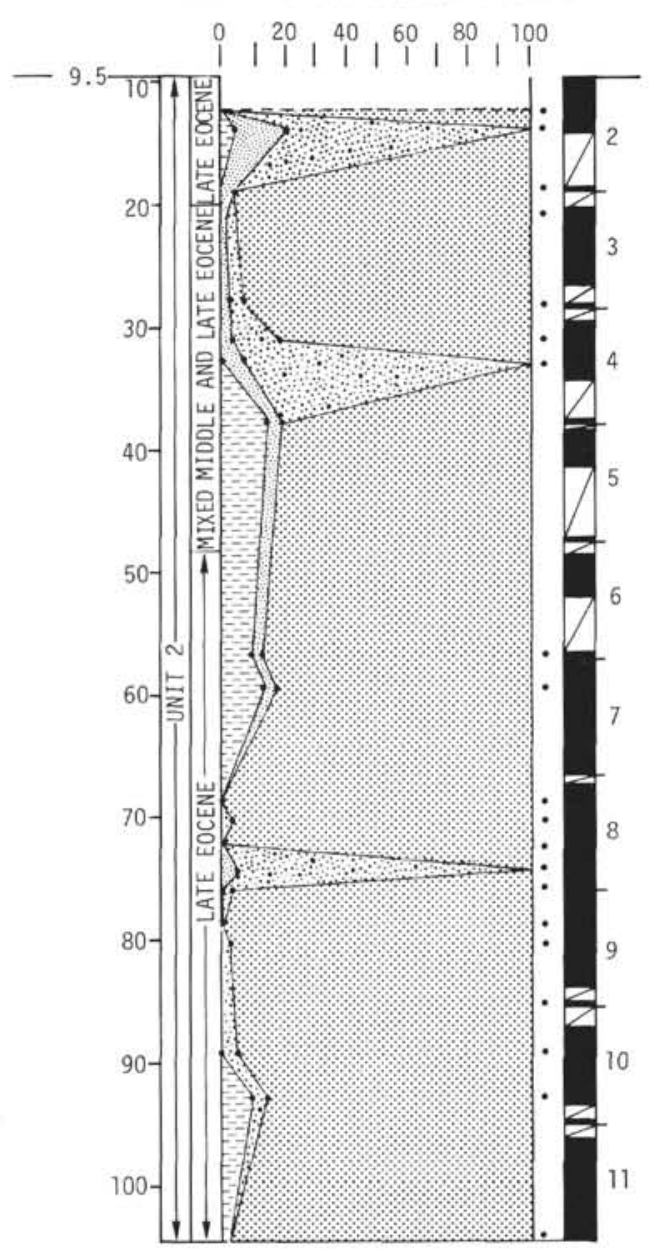

Clay minerals

$\square$ Other terrigenous components

Wolcanic glass

Glauconite

Pelagic siliceous components

Pelagic calcareous components

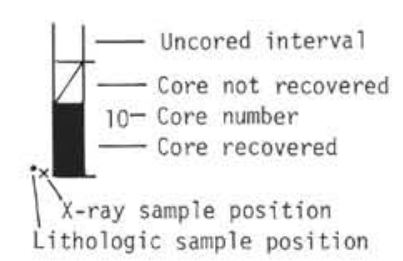

Figure 5. (Continued) 
HOLE 338

PERCENTAGE COMPOSITION OF SAMPLES

Approximate

top of
01 igocene

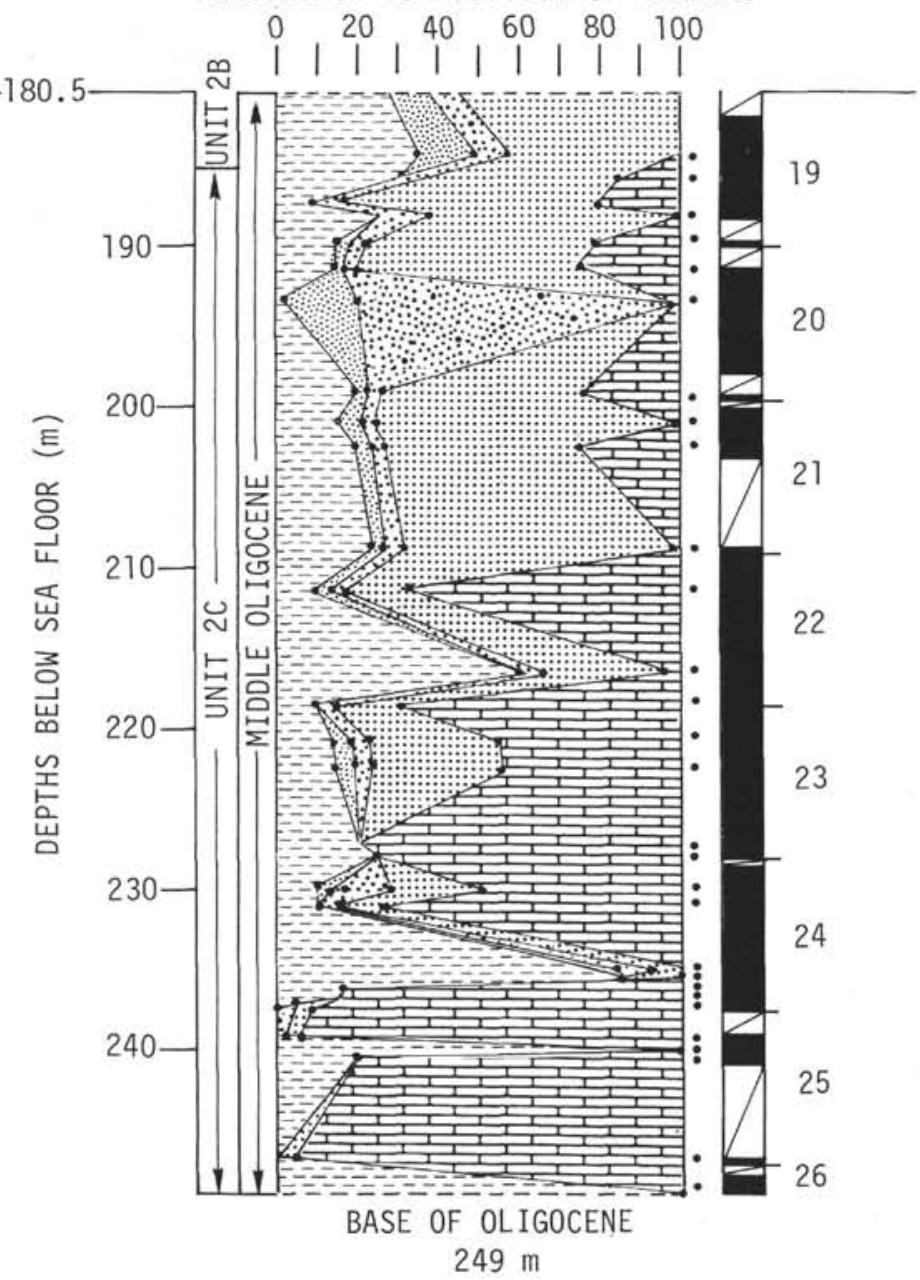

HOLE 339

PERCENTAGE COMPOSITION OF SAMPLES

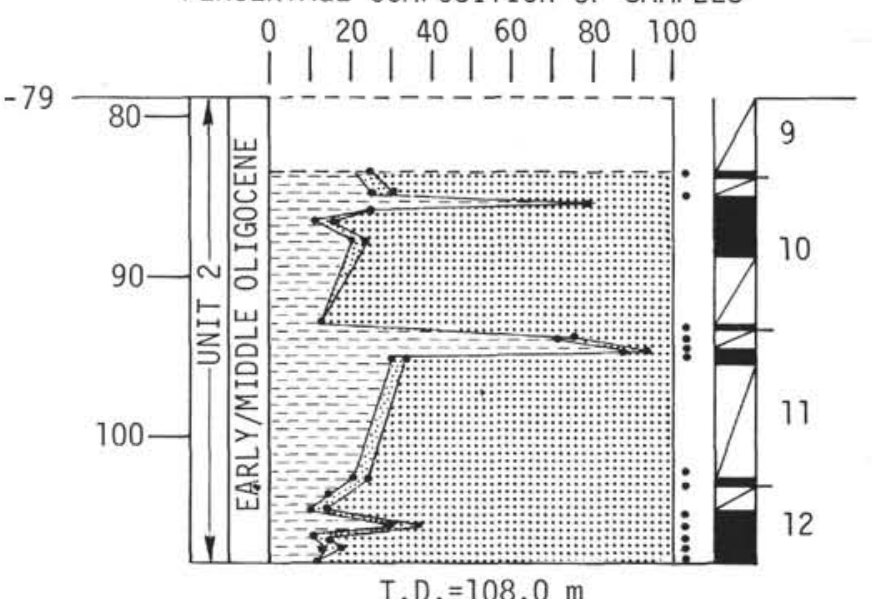

T.D. $=108.0 \mathrm{~m}$

$=-7$ Clay minerals

other terrigenous

components, including Glauconite

Volcanic glass

Pelagic siliceous

Pelagic silit

components

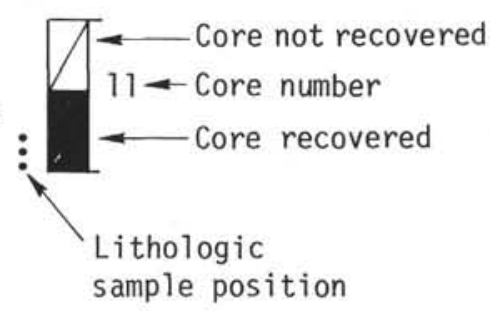

Pelagic calcareous components

Figure 6. Compositional facies diagram for the Oligocene at Sites 338 and 339. This shows lithologic units referred to in text, ages (on micropaleontologic evidence), core positions (including those parts of core recovered), lithologic sample positions, and percentage composition of lithologic samples (smear-slide estimates). 
decrease to $45 \%-50 \%$ in Core 12 . It then remains approximately constant to the top of Core 7 . These variations are mirrored by changes in the percentage of montmorillonite, with kaolinite and chlorite each remaining fairly constant at $12 \%-20 \%$.

Hole 342 was drilled on a local high of acoustic basement, some $27 \mathrm{~km}$ to the northwest of Site 338. This high rises above the reflectors penetrated at the latter site (Figure 2), and, predictably, the Paleogene was absent in the hole, which passed through "Glacial" muds, and Miocene oozes before penetrating basalt at 153.2 meters. Unfortunately, a gap of 28.5 meters between Cores 3 and 4 means that there is only a discontinuous record of Miocene sedimentation. The cores nevertheless reveal a total Miocene thickness of ca. 68 meters, which consists primarily of diatom ooze, with $5 \%$ to $10 \%$ Radiolaria, and $7 \%$ to $18 \%$ sponge spicules, proportions that are comparable with those recorded in the upper part of the middle Miocene sequence (Subunit 2A) at Site 338. This ooze becomes increasingly muddy and impure both towards the base and top (Figure 7). The lower 12.2 meters represents the more terrigenous deposits immediately overlying basaltic basement, the basal sediment consisting of a sandy glauconitic mud. In addition to glauconite, other terrigenous components including clay-size particles $(60 \%)$, volcanic glass, and opaque grains reach a maximum content in the basal sedimentary core.

Core 3 records a rapid upward decrease in the proportion of biogenic ooze, and a corresponding increase in terrigenous material. This is paralleled by a change in the dominant pelagic siliceous component from diatoms to sponge spicules, locally reaching a total of $18 \%$. The overall sedimentary sequence consists of interstratified olive-gray mud and lighter colored spongespicule mud, with occasional streaks of nannofossil ooze.

On the other side of the escarpment, 109.5 meters of middle Miocene sediments were cored in the lower portion of Site 341. A coring gap of only 9.5 meters between Cores 25 and 26 apparently conceals the top of this Miocene succession and the base of the overlying Plio-Pleistocene; it is not known whether there was a hiatus during the late Miocene. The lower part of the sequence from Cores 28 through 34 was continuously cored with nearly $100 \%$ recovery.

The major portion of the sequence consists of massive muddy diatomaceous ooze/muddy diatomite. The siliceous component throughout remains fairly constant at $30 \%-40 \%$ and consists principally of diatoms (15\%-40\%). Radiolaria (3\%-5\%) and sponge spicules $(7 \%-20 \%)$ are present in subordinate quantities. Some $50 \%$ to $60 \%$ clay and other terrigenous material is present throughout the interval from Core 29 through 34 , but is replaced in part in Cores 26 to 28 by significant quantities of calcareous nannofossils. A distinct chalk bed $40 \mathrm{~cm}$ thick is present in Core 26. Composition of the clays, as shown by X-ray diffraction, varies little, with about $25 \%-40 \%$ illite, $25 \%-45 \%$ montmorillonite, $15 \%-20 \%$ kaolinite, and $13 \%-18 \%$ chlorite. Other terrigenous components consist largely of quartz and feldspar (2\%-10\%), mica (1\%-3\%), and opaque grains $(2 \%-5 \%)$. Virtually no heavy minerals or glauconite were recorded.

\section{Pliocene}

Because of difficulties experienced in distinguishing the Pliocene from the Pleistocene in these high latitudes, where glaciation appears to have commenced in the late Tertiary, sediments of unequivocal Pliocene age have not been recognized in any hole drilled on the $\mathrm{V} \phi$ ring Plateau. Sediments of Plio-Pleistocene age were, however, recognized at all but two sites; of these, Site 340 drilled little more than a veneer of "Glacial" sediments overlying Eocene oozes on the diapir. At Site 342 , the Plio-Pleistocene may be present, but has not been recognized because of limited coring in the upper part of the hole. The Plio-Pleistocene boundary cannot be drawn with any degree of accuracy. The presence, at Sites 341 and 343 , of a twofold division of the PlioPleistocene into a lower, fairly competent, stratified unit and an upper, soft and relatively structureless, sandy mud, however, enables a rather arbitrary choice to be made at the top of the lower unit. The boundary clearly reflects a fairly considerable change in depositional environments.

At Site 338, Cores 1 to 3 are dated as Pleistocene and Cores 4 to 6 as Plio-Pleistocene, although there are no very apparent lithological differences between the two. The latter unit will be considered here.

The greater part of Core 4 consists of muddy nannofossil ooze, and minor layers of this lithology together with pure nannofossil ooze are also present in Core 5, although the greater part of this core together with the underlying Core 6 consist of mud and sandy mud (Figure 8 ). These muds are poorly sorted and include up to $25 \%$ quartz and feldspar together with $55 \%-75 \%$ clay minerals; they do not appear to have pelagic components. "Glacial" affinities are suggested by the presence, in Core 5, Section 5, of gneissic pebbles together with sandstone grains with a red matrix. These are characteristic of sediments of undoubted "Glacial" age seen both at shallower depths at this site, and at Sites 341 and 343 .

Moving down the slope of the $\mathrm{V} \phi$ ring Plateau to Site 343 , two discontinuous cores ( 3 and 4 ) were cut in a unit dated as Plio-Pleistocene. These consist primarily of mud and sandy mud with intercalated layers of calcareous mud, particularly in Core 4, and narrow streaks of siliceous ooze, which have approximately equal proportions ( $40 \%$ each) of diatoms and Radiolaria. Quartz percentage varies from $15 \%$ to $65 \%$ in the muds and muddy sands, and red-cemented sandstone grains up to $0.75 \mathrm{~mm}$ (already described from Site 338), are common. The calcareous ooze includes foraminifera, locally up to a total of $60 \%$. Heavy mineral grains are abundant and include many large pyroxenes. They range up to a maximum of $12 \%$. Because of coring gaps, the relationship of this material to the underlying Eocene is not known.

Within the V $\phi$ ring basin, Site 341 possesses the thickest Plio-Pleistocene sequence recorded on the plateau, from 66.5 to ca. 347 meters, a total of ca. 281.5 meters. Of this, the lower 110 meters or so (Cores 20 to 
Hole 342

HOLE 338
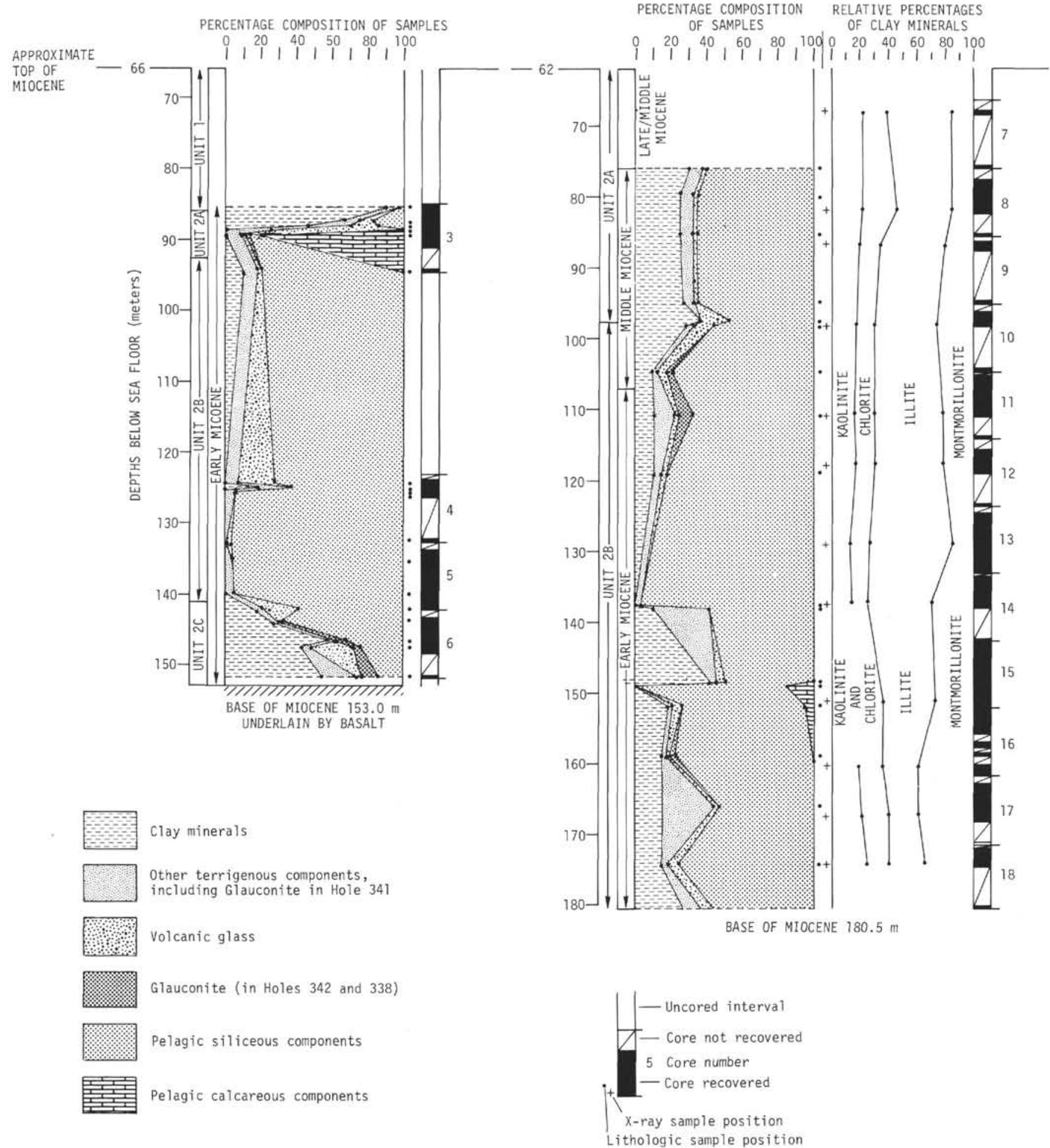

Figure 7. Compositional facies diagram for the Miocene at Sites 338, 341, and 342. This shows lithologic units referred to in text, ages (on micropaleontologic evidence), core positions (including those parts of core recovered), lithologic and $X$-ray sample positions, percentage composition of lithologic samples (smear-slide estimates), and relative proportions of the clay mineral fraction ( $X$-ray diffraction analyses).

25 inclusive) are distinctly stratified, in contrast to the overlying almost structureless dark gray calcareous muds. Only this stratified sequence will be considered here, although considerable coring gaps and few samples in the upper three cores have limited detailed compositional studies in Cores 23-25 (Figure 8).

The stratified material corresponds to interbeds of mud, sandy mud, calcareous mud, and calcareous ooze, 


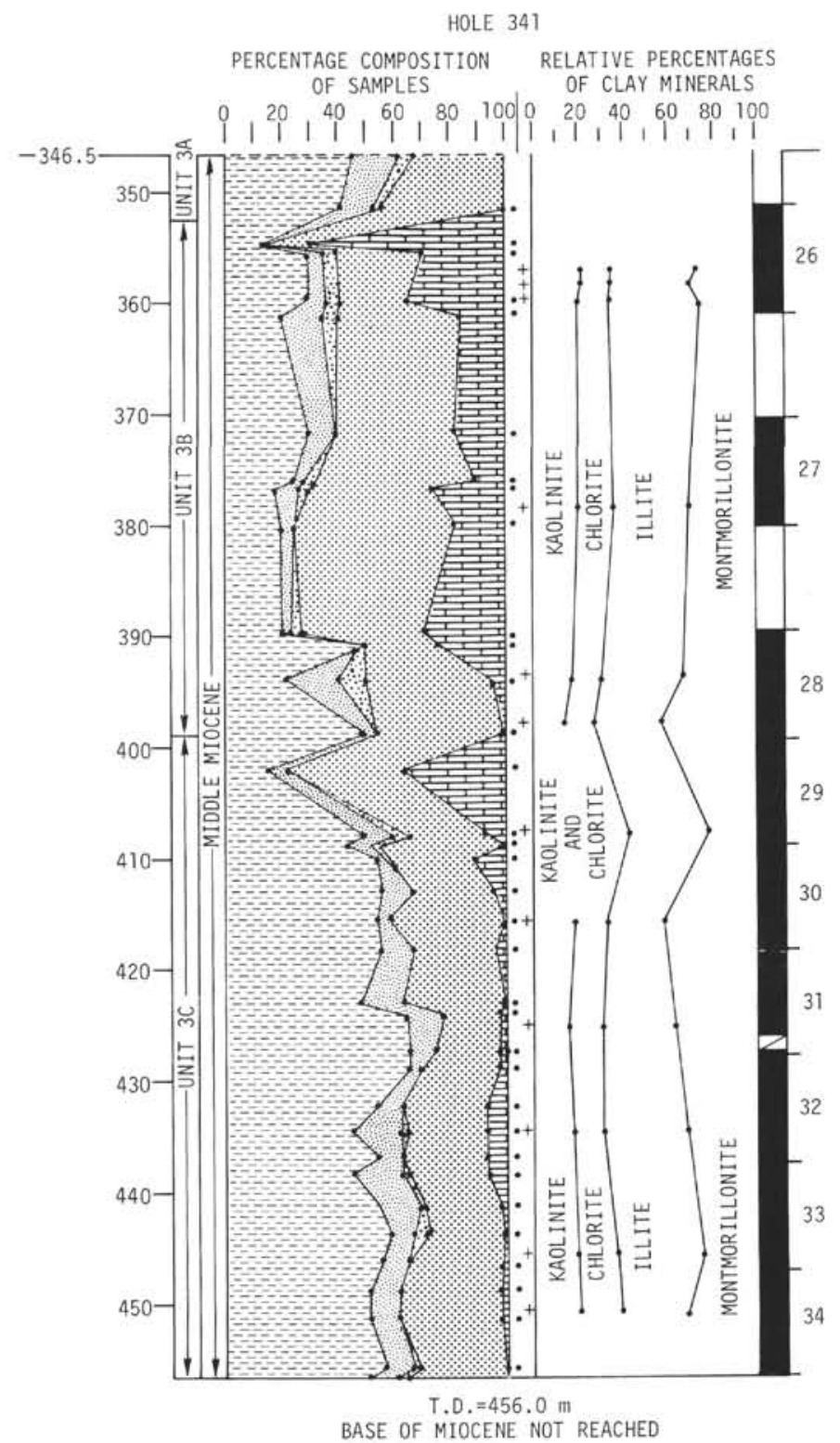

Figure 7. (Continued)

which vary in thickness from 1 to $5 \mathrm{~cm}$ in Cores 20 and 21 to 15 to $65 \mathrm{~cm}$ in Core 24. In part, some of this stratification may consist of turbidites. Color grading from dark to olive-gray, suggestive of graded bedding, is common, and identifiable turbidite sequences in Cores 20 and 21 include graded beds with basal fine sand and small pebbles up to $5 \mathrm{~mm}$ in diameter. Muds commonly consist of $60 \%$ to $80 \%$ clay, dropping to $40 \%$ to $60 \%$ in Core $25,10 \%$ to $20 \%$ quartz and feldspar, and only trace proportions of other terrigenous components. Calcareous ooze and authigenic carbonate (probably altered nannofossils) are present in variable quantities. From $3 \%$ to $5 \%$ lithic fragments, principally of chert and shale, are present in a few samples, and a thin bed of heavy mineral-rich ( $10 \%-15 \%$ total) silt occurs in Core 20, Section 1. The abundance of diatoms, which so characterizes the underlying Miocene sequence, diminishes rapidly from $20 \%$ to ca. $5 \%$ through Core 25 , and in the overlying cores pelagic siliceous material is virtually absent, apart from some $15 \%$ sponge spicules in Core 23, Section 6. Volcanic glass is present throughout Core 25, but is absent in Cores 24 to 20 , even in background quantities; no volcanic ash layers are recorded.

Little can be said about the Plio-Pleistocene at Site 339 except that Cores 7 and 8 appear to represent a zone of mixing between the underlying diatom ooze and the overlying terrigenous glacial deposits. Essentially the cores consist of two principal sediment types: an olive-gray clay and a greenish-gray diatom ooze, which, especially in Core 8, are commonly intermixed to give a muddy diatom ooze. The intermixing is clearly apparent on visual examination.

\section{SEDIMENT DISTRIBUTION}

\section{Correlation with Seismic Profiles}

Five of the sites described were linked by a composite airgun profile shot by Glomar Challenger (Figure 2), the track of which is shown in Figure 3. Onto this has been 
HOLE 343

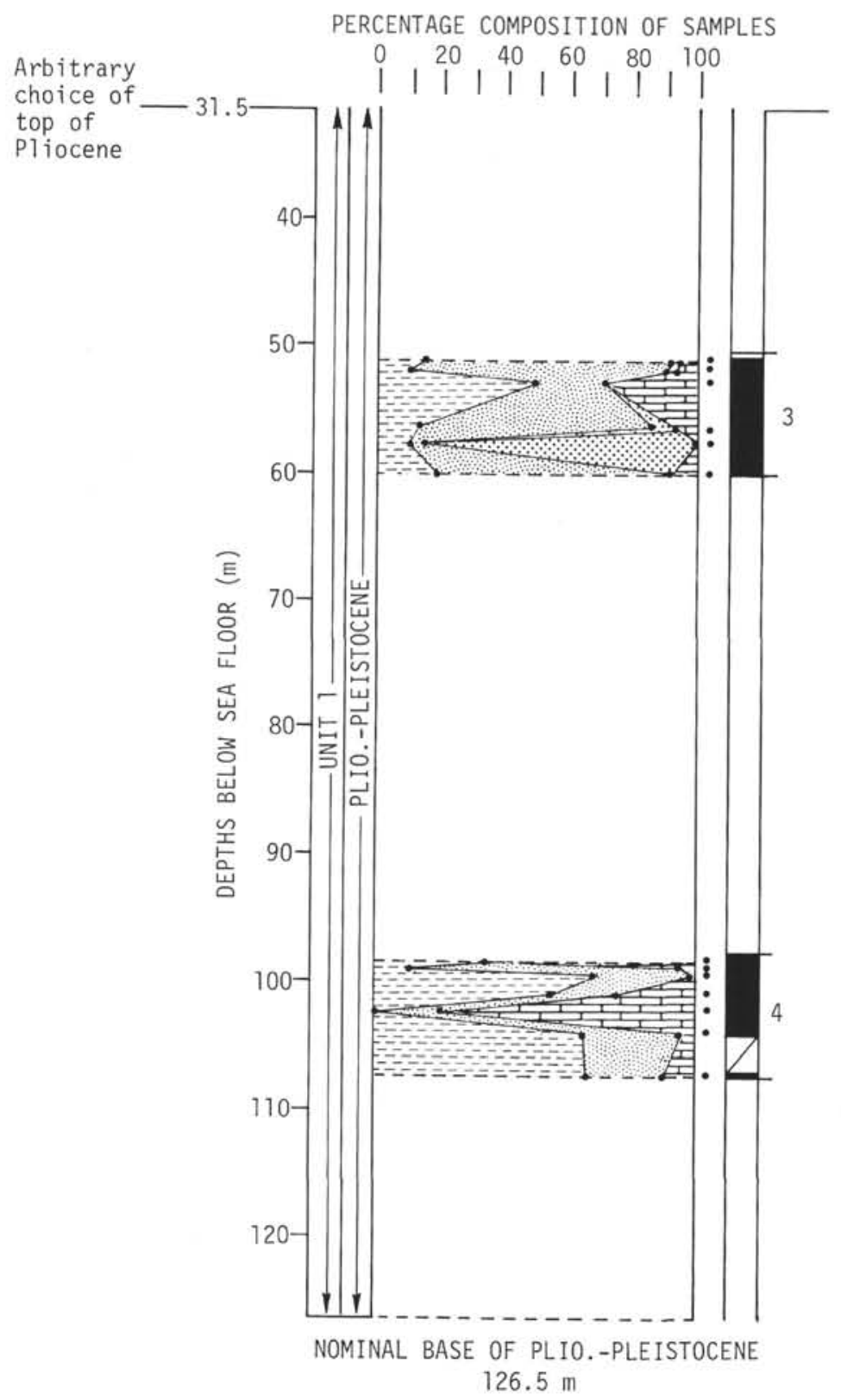

HOLE 338

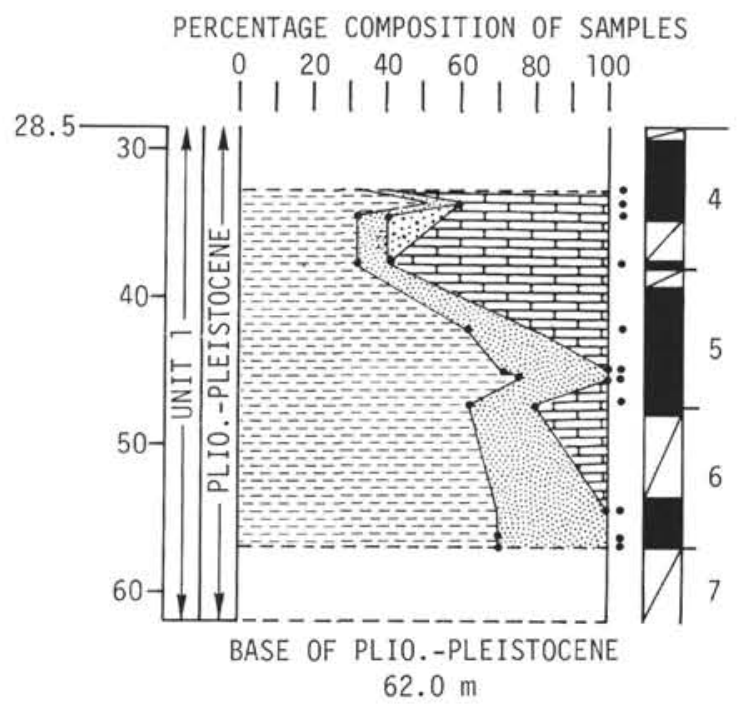

Figure 8. Compositional facies diagram for the Pliocene at Sites 338, 339, 341, and 342. This shows lithologic units referred to in text, ages (on micropaleontologic evidence), core positions (including those parts of core recovered), lithologic sample positions, and percentage composition of lithologic samples (smear-slide estimates).

projected the position of Site 338, which was offset 11 $\mathrm{km}$ away parallel to the escarpment.

Acoustic basement, corresponding to basalt penetrated at Sites 338,342 , and 343 , is clearly identifiable to the northwest of the escarpment. At Site 342 , only one poorly defined reflector at ca. $0.1 \mathrm{sec}$ is apparent above basement, and this is believed to represent the boundary between "Glacial" pebbly mud and the underlying muds and siliceous muds of early Miocene age, which has been recognized at 85.8 meters in the hole.

The picture at Site 338 is more complex, and reference is therefore made to a portion of the airgun profile shot on the approach to the Site (Figures 3,9).
The single sedimentary reflector noted at Site 342 is less obvious at Site 338 and may be at a slightly shallower depth, perhaps $0.08 \mathrm{sec}$. It probably corresponds to the Plio-Pleistocene/middle to late Miocene boundary plotted at 61 meters. The next reflector, which is faint, but identifiable both at this and at approximately the same depth in Figure 2) lies at a depth of ca. $0.27 \mathrm{sec}$ and may well represent the top of the calcareous diatom ooze layer at 160 meters, which marks the Miocene/Oligocene boundary. Underlying this, at $0.31 \mathrm{sec}$, is the top of a fairly prominent multiple reflector also recognizable as a significant feature on the longer profile (Figure 2). This is believed to correspond to the 
HOLE 341

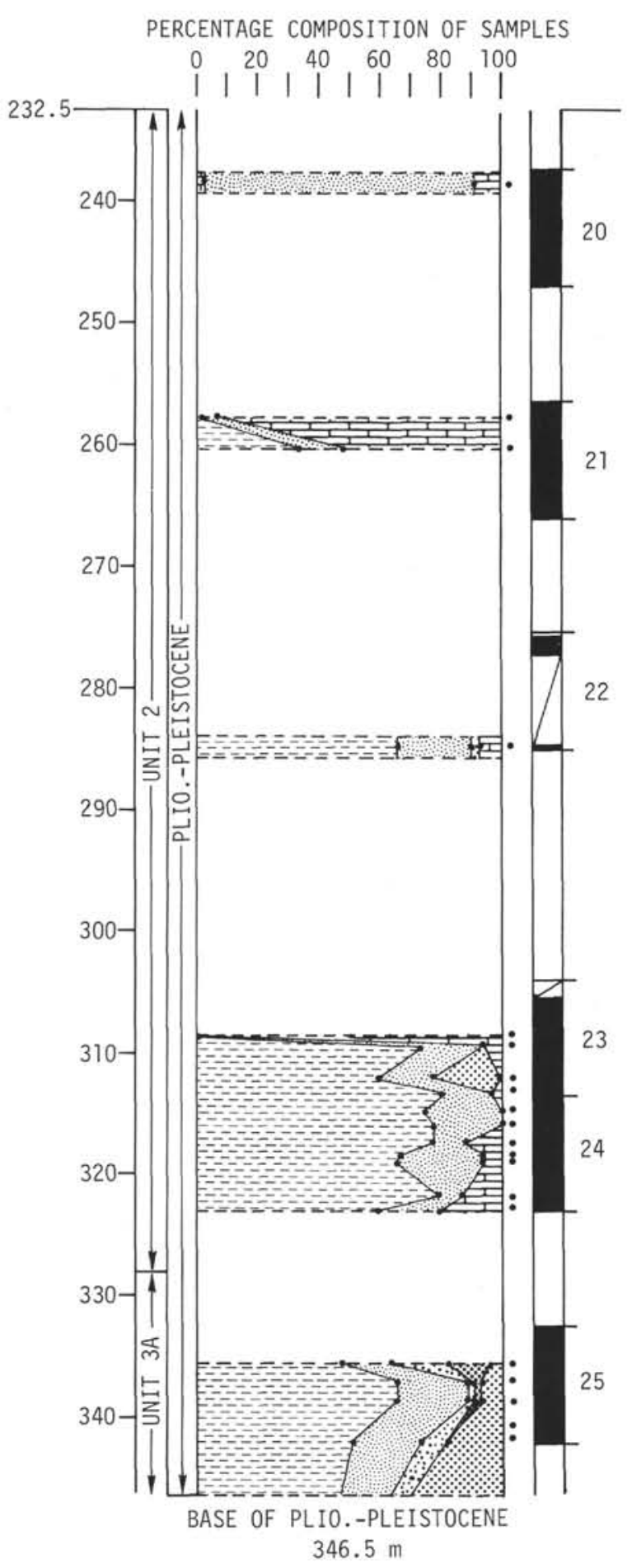

Figure 8. (Continued)

abrupt increase in sediment competency and velocity recorded at or about the top of Core 24 , or ca. 228 meters (see Site 338 Report, this volume). This would date the reflector at about the mid-middle Oligocene, or approximately $30 \mathrm{~m} . \mathrm{y}$. A prominent reflector $0.06 \mathrm{sec}$ below this, at $0.37 \mathrm{sec}$, which passes undisturbed below the diapir-like feature, is believed to represent the glauconitic sands and muddy sands at 285 meters, the
HOLE 339

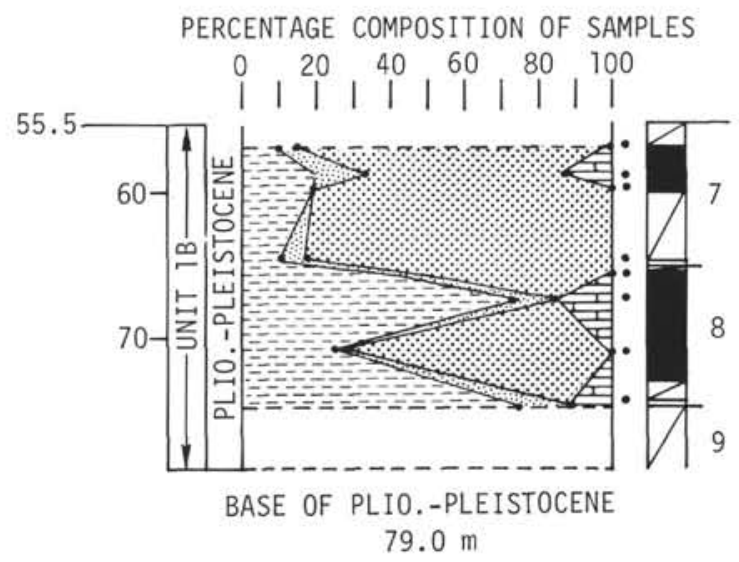

Clay minerals
Other terrigenous components,
including Glauconite (except
in Hole 341 )
Volcanic glass

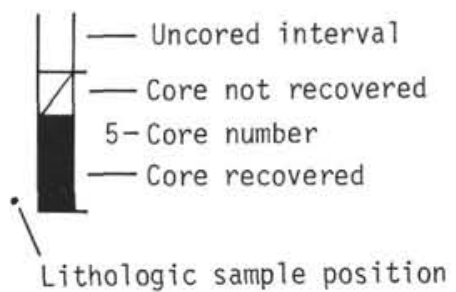

top of the early Eocene terrigenous sequence. This reflector is visible in Figure 2 at about this depth, but is less prominent.

The higher velocity layer noted in the lower part of the early Eocene at a depth of ca. 342 meters, and the top of which at the velocities measured (Site 338 Report, this volume) should appear on the profile at $0.42 \mathrm{sec}$, is surprisingly absent on the reflection record. 

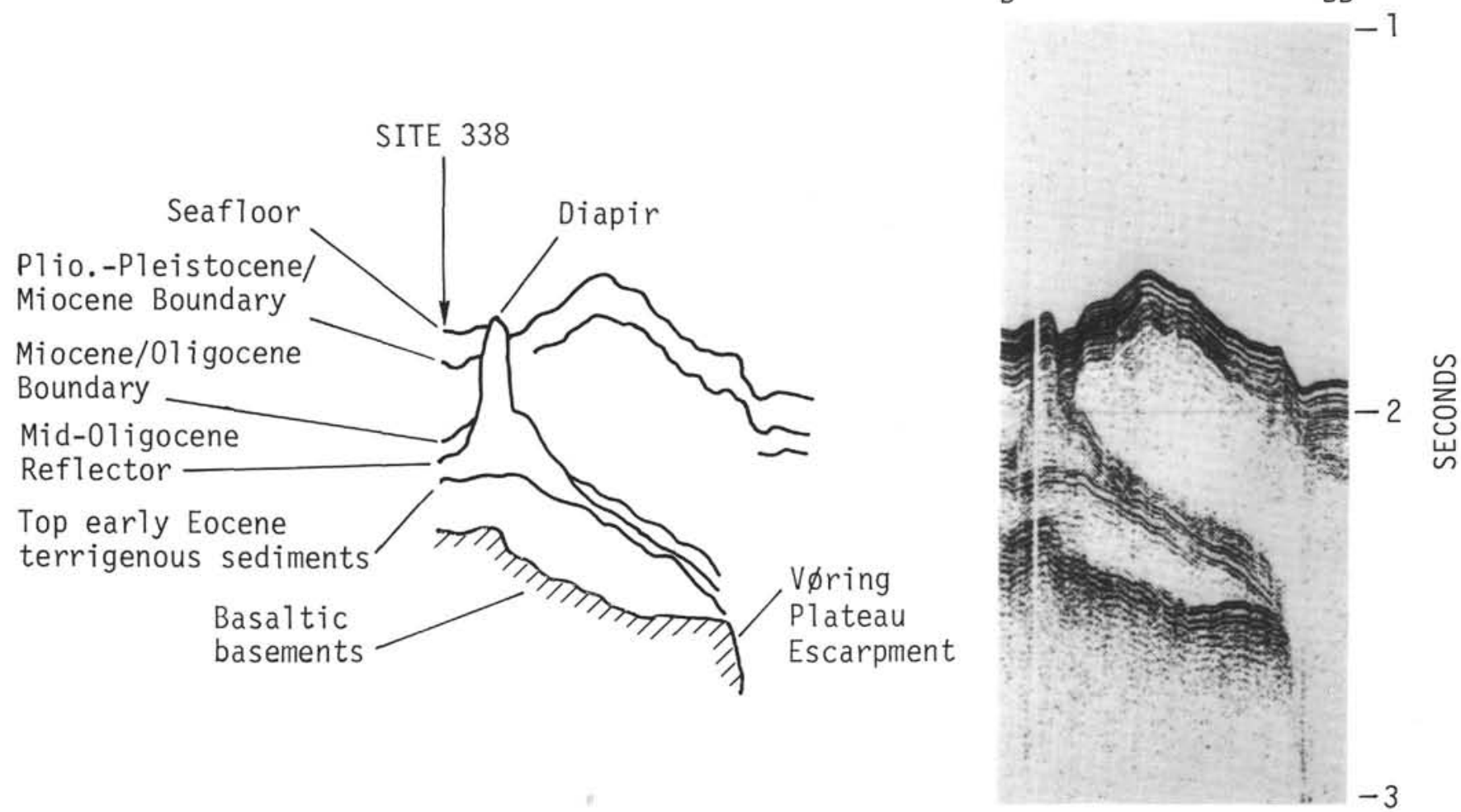

Figure 9. Airgun profile B-BB shot by Glomar Challenger en route to Site 338, together with interpreted section. See text.

The apparent diapir seen on this profile, and recognizable, to a lesser extent, in Figure 2, will be discussed below.

In Figure 2, the profile record at Site 343 is not clear, but midway between sea bed and basement there appears to be a seaward-dipping reflector at about 0.16 sec. By assuming an average velocity of $1.687 \mathrm{~km} / \mathrm{sec}$ measured in the upper portion of the hole, this is equivalent to a depth of 134 meters, which agrees fairly closely with the estimated Plio-Pleistocene/middle Eocene boundary.

Within the V $\phi$ ring Plateau basin, correlation is not possible between Sites 339/340 and the very diffuse character of the airgun record in the diapir area. Doming-up of deeper reflectors around the perimeter of this diapir area is, however, very apparent. There is evidence from both this and from a study of other profiles in the area (Talwani and Caston, in preparation) that the diapir area is located above a structural high of possible pre-Tertiary age. Reflectors are apparent in the basin (Figure 2) down to a depth of $1.1 \mathrm{sec}$. Site 341 terminated in the middle Miocene at a depth of 456 meters, equivalent to an approximate penetration of $0.56 \mathrm{sec}$. Unfortunately, velocity information is not available below Core 5, and therefore only very approximate correlations can be attempted based upon an average velocity of $1.56 \mathrm{~km} / \mathrm{sec}$ determined in these uppermost cores. This enables the PlioPleistocene/middle to late Miocene boundary at 328.0 meters to be equated fairly well with a reflector at 0.42 $\mathrm{sec}$, but provides a less precise correlation between the Unit 1/Unit 2 boundary (Site 341 Report, this volume) within the Plio-Pleistocene, and a fairly well defined reflector at $0.27 \mathrm{sec}$.

The outstanding problems posed by these profiles are: (1) the age of the prominent reflector present on the outer part of the plateau between, but not sampled by, Sites 342 and 343 . Below about $3.5 \mathrm{sec}$ subsea level, this is clearly an unconformity. This corresponds to the interface separating layers with velocities of 1.7 and 2.2 $\mathrm{km} / \mathrm{sec}$ defined on the basis of reflection and refraction work by Talwani and Eldholm (1972); (2) the age of the prominent reflector lying at $0.7 \mathrm{sec}$ below Site 341, which can be followed westward to the escarpment where it lies at a depth of $0.6 \mathrm{sec}$. This similarly corresponds to an interface identified by Talwani and Eldholm (1972) as separating layers with velocities of 1.8 and $2.2 \mathrm{~km} / \mathrm{sec}$. (3) the ages of the deeper reflectors, visible at ca. 0.96 and $1.1 \mathrm{sec}$, which also lie below Site 341 . These can be traced intermittently westward to the escarpment, and may correspond approximately to Talwani and Eldholm's $2.2 / 2.5 \mathrm{~km} / \mathrm{sec}$ interface.

As far as (1) and (2) are concerned, work in progress (Talwani and Caston) has shown that both reflectors can be traced via seismic profiles to the southern end of the escarpment until they meet, and that they are the same feature. Detailed mapping from profiles in the vicinity of Sites 338 and 342, described below, strongly suggests that this reflector is correlatable with the dominant middle Oligocene reflector present immediately to the east of the basement high seen in Figure 2 and sampled at Site 338. The direct evidence is, however, ambiguous because of the occurrence in this localized area of several closely spaced reflectors rang- 
ing in age from early Eocene to Oligocene/Miocene. Supporting evidence is forthcoming from a consideration of the nature of this middle Oligocene horizon. It appears to be related to and perhaps directly caused by a significant influx of calcareous nannoplankton into an otherwise dominantly siliceous ooze sequence. Such an event is unlikely to have been of purely local occurrence (in comparison with the early Eocene glauconitic sands, for instance) and would be expected to extend throughout this area of the Norwegian continental margin. In this case it would be apparent as a basinwide reflector.

The unconformable deeper water extension of the reflector is probably a local phenomenon caused by a contour current flowing around the base of the plateau. This current may have owed its existence to the events and possible changes in circulation pattern which were responsible for the abrupt influx of calcareous nannoplankton in the middle Oligocene.

There is no direct information concerning the ages of the deeper reflectors in the $\mathrm{V} \phi$ ring Plateau basin (Figure 2). On the basis of refraction results, and making the assumption that Tertiary sediments have velocities of $2.5 \mathrm{~km} / \mathrm{sec}$ or lower (Talwani and Eldholm, 1972), then the base of the Tertiary lies at a depth of 1.8 or $1.9 \mathrm{sec}$ subsea bed in the vicinity of Site 341. Thus, the reflectors seen must lie within the lower Oligocene or Eocene.

\section{Deposition of Paleogene Sediments Around Basement Highs}

The Glomar Challenger profile (Figure 2) shows that the pre-middle Oligocene sediments penetrated at Site 338 are absent over the crest of a basement high drilled at Site 342. Examination of a number of additional profiles shot by R.V. Vema in this area has confirmed this relationship and has revealed that there are probably three such basement highs projecting above the presumed mid-Oligocene age reflector to the northwest of the escarpment (Figure 10). Gaps in the line coverage, however, mean that a sediment connection between highs " $A$ " and " $B$ " cannot be proved, in which case a basement ridge between these two features may have persisted at least until mid-Oligocene time. The Paleogene isopach map (Figure 11) is, however, believed to represent the most likely distribution.

Shown also in Figure 10 is the zero thickness line for this Paleogene unit, which has a westerly or northwesterly dip from about $1.8 \mathrm{sec}$ to $2.4 \mathrm{sec}$ around high "A," from 2.0 to $2.1 \mathrm{sec}$ on high "B," and from 1.9 to ca. $2.3 \mathrm{sec}$ on high "C." Much of this is probably an original sedimentary distribution related to basement relief, especially as in high " $\mathrm{C}$ " there is some indication of a reversal of this trend (from 1.9 to $2.1 \mathrm{sec}$ ) on the southeastern side of the feature adjacent to the escarpment. Examination of the airgun profile (Figure 2), however, shows that the reflectors at Site 338 are at the same depth, if not slightly shallower, than the depth at which they lap onto basement high "B." This is suggestive of slight postdepositional tilting rather than the result of an original sedimentary process, and supports a suggestion that in the observed sediment distribution pattern around the basement highs there may be a component of postdepositional seaward tilt.

\section{Sediment Thickness and Movement of the V $\phi$ ring Plateau Escarpment}

The Glomar Challenger profile (Figure 2) confirms that the outer part of the plateau consists of a buried basement ridge mantled by sediment. This sediment infills the V $\phi$ ring Plateau basin to the southeast of the ridge, the edge of which is formed by the V $\phi$ ring Plateau Escarpment, and on the northwestern side it forms a thickening downslope wedge. Thicknesses vary from a minimum of $0.2 \mathrm{sec}$ (153 m at Site 342) on top of the ridge to $1.4+\sec$ near the base of the slope, and $1.95 \mathrm{sec}$ (over $2 \mathrm{~km}$ according to Talwani and Eldholm, 1972) to the proposed base of the Tertiary at Site 341 in the V $\phi$ ring Plateau basin. It is significant to compare approximate sediment thicknesses between Site 338 near the top of the ridge and Site 341 situated in the basin (Table 2).

This comparison implies that throughout the Tertiary there was a relief contrast between the V $\phi$ ring Plateau basin and the ridge to the northwest of the escarpment, the escarpment acting throughout as a sediment dam. Its influence is well illustrated by the presence at Site 341 of Pliocene turbidites, and their apparent absence at Sites 338 and 342. It is suggested that such a dam would have been more effective at ponding terrigenous sediment derived from a continental source to the east than in controlling the distribution of pelagic sediments deposited over the whole area. This would explain both the apparent difference between the ratios at Sites 338 and 341 of Plio-Pleistocene terrigenous sediments (1:5.2) and Miocene oozes (1:1.5), and also the estimated Paleogene ratio (1:5.4), which presumably reflects a dominance of terrigenous sediments in the early and middle Eocene. On this basis, anticipated Oligocene thickness in the basin might be calculated by applying the estimated Miocene ratio, giving perhaps $0.15 \mathrm{sec}$, or $50 \%$ more than that deposited at Site 338, which would leave a very considerable Eocene thickness of $1.1 \mathrm{sec}$ or more.

It is possible that the basin was present as a deep "hole" from early Tertiary time, and that it has progressively filled up through the Tertiary. However, it is more likely that during this period there has been approximate balance between sedimentation and subsidence, and that the basin has subsided more rapidly than the crust seaward of the escarpment. The escarpment would therefore have acted as a normal fault throughout the Tertiary. There is the following support for this hypothesis:

1) The attitude of the reflectors seen in cross-sections of the basin, including the airgun profile (Figure 2), and the refraction profile illustrated by Talwani and Eldholm (1972), which appear as though they may have been dragged up by fault movement, the lowest reflectors having the greatest deflection.

2) The tilting of the mid-Oligocene reflector to the west of the escarpment (discussed above).

3) The bathymetry of the immediate area (Figure 3) coupled with the cross-section (Figure 2), shows that the shallowest part of this portion of the plateau con- 


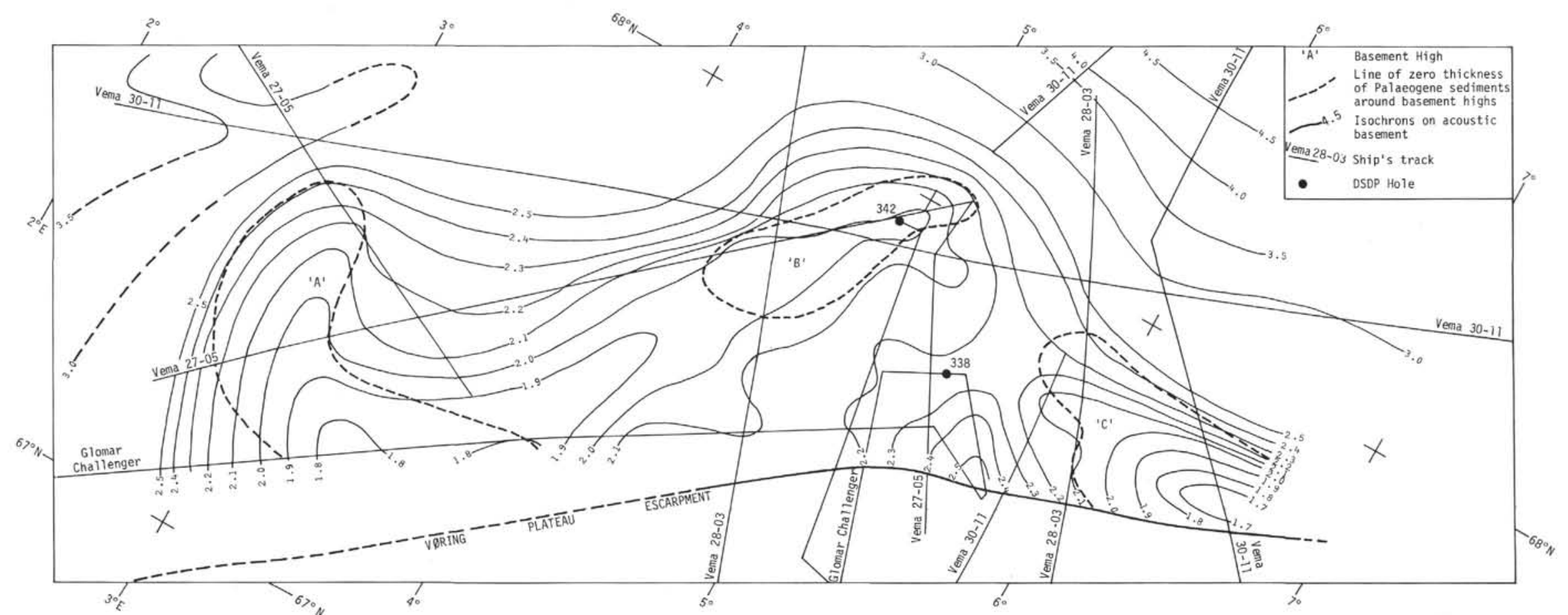

Figure 10. Isochrons on acoustic basement to northwest of Vbring Plateau based upon profiles shot by $R$. V. Vema and D. V. Glomar Challenger. Also shown is zero thickness line of Paleogene sedimentary unit encircling basement highs " $A$," " $B$," and " $C$." 


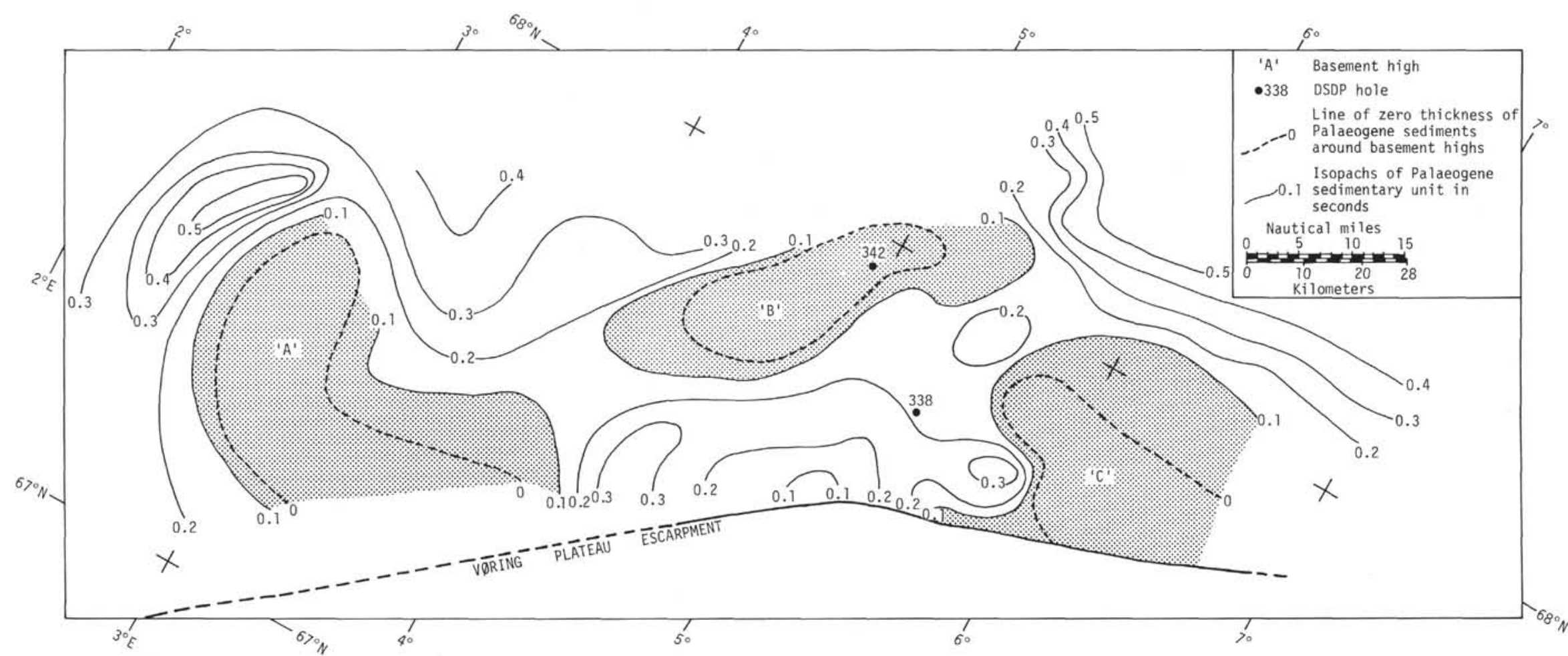

Figure 11. Isopach map (in sec) of Paleogene sedimentary unit (below mid-Oligocene reflector) surrounding basement highs " $A$," " $B$," " $C$ " to the northwest of escarpment. 
TABLE 2

Approximate Relative Thicknesses (sec) of Tertiary Strata at Sites 338 and 341

\begin{tabular}{|c|c|c|c|}
\hline & $\begin{array}{c}\text { Site } 338 \\
\text { (sec) }\end{array}$ & $\begin{array}{l}\text { Site } 341 \\
\text { (sec) }\end{array}$ & $\begin{array}{c}\text { Ratio } \\
\text { Between } \\
\text { Site } 338 / 341 \\
\text { Thicknesses }\end{array}$ \\
\hline Total Tertiary & 0.5 & $1.95 \mathrm{a}$ & $1: 3.9$ \\
\hline Plio-Pleistocene & 0.08 & 0.42 & $1: 5.2$ \\
\hline Miocene & 0.19 & $0.29 \mathrm{a}$ & $1: 1.5$ \\
\hline Oligocene & 0.10 & $1.24 \mathrm{a}$ & $1: 5.4$ \\
\hline Eocene & 0.13 & $1.24 a$ & \\
\hline
\end{tabular}

${ }^{\mathrm{a}}$ Estimated from profiler records only.

sists of a linear feature paralleling the escarpment only some 5 to $7 \mathrm{~km}$ to the northwest.

4) The sediment deformation seen in Figure 2 immediately above the projected plane of the escarpment, and the lack of any reflectors continuing across this critical zone.

5) In connection with (3) and (4) above, the apparent diapirism seen as an incipient feature in the top Oligocene reflector of Figure 2, but shown fully developed in an adjacent profile shot en route to Site 338 (Figure 9). This is discussed below, and it is suggested that the triggering action might have been movement along the fault plane.

6) The wavy appearance of the reflector marking the Miocene/Plio-Pleistocene boundary (Figure 2), which is suggestive of incipient gravity sliding by the overlying terrigenous deposits in response to postdepositional subsidence of the basin.

The surface expression of the escarpment, mentioned in (3) above and illustrated in Figure 2, moreover suggests that the fault movements are still continuing.

\section{Mechanism and Age of Diapirism}

Diapirism was recorded in two areas of the $\mathrm{V} \phi$ ring Plateau during the course of Leg 38 . The principal occurrence involved the diapir complex centered at $67^{\circ} 12^{\prime} \mathrm{N}, 6^{\circ} 14^{\prime} \mathrm{E}$, first described by Talwani and Eldholm (1972), and drilled at Sites 339 and 340. The second occurrence was observed on seismic reflection profiles in the vicinity of the V $\phi$ ring Plateau Escarpment.

\section{Diapir Complex}

The evidence from Sites 339 and 340 (Site 340 Report, this volume) suggests that these diapirs are not composed of salt, but are a variety of the so-called "clay" diapirs, with a core of Eocene to perhaps Pliocene siliceous oozes. Clay diapirs have a worldwide distribution and are commonly present in young sedimentary basins during the terminal regressive stages of a major marine cycle (Chapman, 1973). The ideal circumstances for diapirism are the presence of a porous and permeable load of relatively high density, commonly sand, overlying porous but relatively impermeable clays, thus providing a density imbalance coupled with abnormal interstitial fluid pressures in the clay (Chapman, 1974).
In the present case, the gravity instability is provided by at least 328 meters of muds and sandy muds of PlioPleistocene age, which have a mean bulk wet density of $1.846 \mathrm{~g} / \mathrm{cc}$ and a porosity of $51 \%$. These overlie a considerable thickness of oozes with a mean density (at least at Site 339) of $1.324 \mathrm{~g} / \mathrm{cc}$ and a porosity of $82 \%$ (Site 339 Report, this volume). Permeabilities in the Miocene oozes are near zero (Caston, unpublished data, 1975). Although the total thickness of the ooze is not known and the densities of both overburden and the diapiric material are considerably lower than those discussed by Chapman (1974), it is suggested that the lithological and density variations observed would be sufficient to initiate diapirism.

This leads to a consideration of the age of diapir formation. The nature of the pre-Miocene sediments within the V $\phi$ ring Plateau basin can only be deduced from fragmentary evidence provided by the three holes drilled on this side of the escarpment. Diatom oozes of middle to late Eocene age are present at Site 340, and of early to middle Oligocene age at Site 339 , whereas a mixture of Oligocene to Pliocene age siliceous oozes were identified in the allochthonous unit within the Plio-Pleistocene succession at Site 341. This does not exclude the possible presence of terrigenous sediments, but a comparison with Site 338 suggests that sedimentation in the basin from at least late Eocene to late Miocene times consisted almost wholly of pelagic oozes. The necessary density imbalance was, therefore, not available until the deposition of terrigenous sediments in the Plio-Pleistocene, and even then, not until a sufficient (but unknown) thickness of these muds and sandy muds had accumulated.

The diapirs appear from profiler records (Talwani and Caston, in preparation) to be located immediately above a structural high at a depth of approximately 1.3 sec subsea bed. It is presumed that this feature, or perhaps some associated lines of weakness, would have provided a locus for diapiric activity. The very considerable surface relief of the diapir field, and the virtual absence of Pleistocene and/or Holocene deposits in the crestal zones proved by Bjørklund and Kellogg (1972) and Site 340, suggests that a certain amount of post-Pleistocene movement may also have occurred; indeed may still be occurring. The diapirs seen here and perhaps elsewhere on the Norwegian continental margin (Talwani and Eldholm, 1972), may therefore represent extremely late-stage features in the development of the Norwegian Sea.

\section{Vóring Plateau Escarpment}

Figure 9 shows an apparent diapiric intrusion rising from a well-defined horizon lying just to the northwest of the V $\phi$ ring Plateau Escarpment. A similar feature, though less developed, is shown in the equivalent position on the adjacent line (Figure 2). The diapiric material appears to originate at the level of the late Eocene or mid-Oligocene age oozes; it is underlain by a reflector believed to represent the upper surface of the early Eocene terrigenous sediments. At least in the area of Site 338 (Figure 9), the diapiric material reaches the sea bed, having passed through $0.3 \mathrm{sec}$ of overlying sediment. 
A similar situation to that described for the $\mathrm{V} \phi$ ring Plateau basin exists at this site, with relatively high density terrigenous sediments of Plio-Pleistocene age overlying late Eocene to Miocene pelagic oozes. The thicknesses are, of course, very much less, but it is suggested that, as in the basin, conditions for diapiric growth did not exist until deposition of terrigenous sediments in the Plio-Pleistocene. The location of the diapir may have been influenced by at least three factors, all of which may have had some effect: (1) The diapir is situated at the top of a band of reflectors that dip fairly abruptly towards the V $\phi$ ring Plateau basin. Downward compressional forces caused by overburden pressure would have the effect of squeezing unconsolidated oozes up this planar surface; (2) Reactivation of fault movement along the V $\phi$ ring Plateau Escarpment, downthrowing the basin, would accentuate the situation described in (1) above, and might provide planes of weakness along which diapirism would develop; and (3) The basement reflector (Figure 9) has an abrupt step of about $0.1 \mathrm{sec}$ amplitude immediately below the diapir. This might mark the line of a minor fault, the movement of which could have initiated diapirism (although there is no evidence of any dislocation in the subdiapir reflector).

Whatever the individual cause, all three factors are related to the position of the V $\phi$ ring Plateau Escarpment, and the presence of diapiric structures of this nature is therefore predicted along the line of maximum uplift of this feature.

\section{SEDIMENTARY/TECTONIC HISTORY}

Apart from a thin band of sandy limestone and basalt breccia immediately overlying basement at Site 338 , which is undated, the oldest sediments recovered in this series of sites are those of early Eocene age found at Sites 338 and 343 , which on nannofossil evidence are dated as Zone NP 12, ca. 51-52 m.y. (see Müller, this volume). These sediments consist of sandy muds (Site 338) and muds (Site 343). The latter include a turbidite sequence composed of mudstone and/or decomposed basalt pebbles and grains, thus implying, first, that at this time, as at present, Site 343 lay at the base of a slope, and, second, that the turbidite source further up this slope consisted dominantly of eroded basalt. There is little evidence of derived continental (sialic) material. Possible shell debris present in muds just below the turbidite sequence may also have been brought in from an upslope shallow-water source. At Site 338 , located just below and to the southeast of the summit of the presumed early Eocene basement ridge (Figure 2), the overall early Eocene succession is coarser grained than that at Site 343. This suggests a location closer to the sediment source and/or a relatively higher energy environment. The presence of decomposed basalt fragments throughout this terrigenous sequence indicates that a basalt source was being eroded until uppermost early Eocene times and, depending upon the age of the glauconitic sandy muds in Cores 30 and 31, possibly into the middle Eocene. There is, however, evidence in these coarser grained sediments, including the occurrence of mica, feldspar, and locally up to $50 \%$ quartz, of the additional presence of a continental-type source.
The distribution of Paleogene sediments around three basement highs in this area to the northwest of the escarpment has been described in a previous section. At least in high "B," drilled at Site 342, sedimentation did not commence until the middle Miocene. Energy levels over these highs were therefore sufficient to inhibit sedimentation for this period of time. It is suggested (there is no direct evidence) that during the early Eocene active erosion was taking place, contributing basaltic fragments to the surrounding sediments. Origin of continental-type sediments in the Eocene succession is not so conveniently explained. There are at least four alternatives: (1) It is possible that the V $\phi$ ring basin as a topographic feature was not in existence, and sedimentary particles derived from erosion of the Scandinavian landmass could reach the ridge. However, in a previous section it has been suggested that there is a very considerable difference in relative Eocene thicknesses on either side of the escarpment. Therefore, the basin was certainly active during this period, although its paleotopography vis-a-vis the escarpment is not known. (2) If it is believed that the crust to the northwest of the escarpment consists of a continental fragment covered with basalt, then it is possible that erosion of one of the basement highs might have exposed continental-type sediments. (3) Detailed studies of seismic profiles in this area (Talwani and Caston, in preparation) has shown that pre- or very early Tertiary sediments approach close to the sea bed in the northern part of the basin already recognized as the "outer high" (Talwani and Eldholm, 1972). This area has clearly acted as a positive feature throughout the Tertiary and, if close to sea level, may have acted as a sediment source in the Eocene. (4) Dr. Olaf Eldholm (personal communication) has pointed out that at this early stage of development of the Norwegian-Greenland Sea a part of the Greenland margin would have lain adjacent to the V $\phi$ ring Plateau along the Jan-Mayen Fracture Zone, and thus perhaps acted as a sediment source.

Whatever the source(s), the supply of terrigenous sediment to this outer part of the plateau ceased abruptly at the end of the early Eocene (49-50 m.y.) at Site 343 , and at this time or during the middle Eocene (43-49 m.y.) at Site 338. At both sites, the uppermost terrigenous deposits include a number of ash horizons, indicative of active volcanism. This abrupt cessation may have resulted from the plateau sinking below erosive level, or, as Eldholm (personal communication) has suggested, the final separation of the Greenland and Norwegian margins along the Jan-Mayen Fracture Zone. Even if not directly responsible for cutting off the supply of terrigenous sediments, this split might have been the cause of the abrupt subsidence of the V $\phi$ ring Plateau and/or a major change in the oceanic circulation pattern. Either (or both) would be directly responsible for the observed change in sedimentation.

Dominantly pelagic sedimentation succeeded terrigenous at Site 343 during the middle Eocene, with no apparent hiatus between the two. At Site 338, however, and assuming that the glauconitic sands of Core 30 are of early Eocene age, there was a hiatus throughout the middle Eocene, indicating that on the surface of the plateau energy levels were still sufficiently high to inhibit sediment accumulation. These 
levels diminished sufficiently, presumably because of subsidence, to permit deposition at this site by the late Eocene, and, ultimately, on the basement highs during the early Miocene (ca. 20 m.y.).

This sedimentary evidence clearly points to the progressive subsidence of the $\mathrm{V} \phi$ ring Plateau through to the early Miocene. From the plateau's present subsea-level depth of ca. $1.5 \mathrm{~km}$, it is probable that this subsidence has continued during the Neogene. However, localized currents of relatively high velocity may have swept the basement highs free of sediment to quite considerable water depths, so the depth of the plateau at the time of commencement of pelagic deposition in the Miocene is not known. On this basis a subsidence/time curve could therefore only show that the plateau has sunk approximately $1.5 \mathrm{~km}$ in about 50 m.y.

Because of limited core data, the oldest pre-Pliocene sediments recognized at Site 343 are of middle Eocene age. For reasons already discussed, it is, however, suggested that sedimentation may have continued here until the proposed mid-Oligocene change in circulation pattern responsible for the influx of calcareous nannofossils, and the commencement of the erosive contour current flow at the base of the plateau. This current appears to have restricted sedimentation at this site until deposition of terrigenous sediments commenced again in the Plio-Pleistocene. At Site 338, there may have been a short hiatus in the late Oligocene and at Site 342, during the middle and late Miocene. However, at the latter site, this may be more apparent than real because of limited core recovery. Otherwise, biogenic pelagic sedimentation, supplemented by varying amounts of hemipelagic terrigenous material, continued to the Pliocene. It is interesting to note that terrigenous content of the Eocene and Oligocene age oozes cored in the basin is lower than those of comparable age to the northwest of the escarpment, but that by the middle Miocene the situation is reversed. This may reflect the different relative importance of sediment sources through the Tertiary, clay from local erosion or reworking of sediments contaminating pelagic ooze deposited around the basement highs during the Paleogene, whereas by the Miocene the topographically low basin was acting as a sediment sink relative to the sea floor to the northwest of the escarpment and receiving terrigenous material derived from a source to the east.

The Plio-Pleistocene commenced with the incursion of terrigenous deposits, at least, in part, brought by turbidity currents, into the V $\phi$ ring Plateau basin. Similar layered deposits are also recorded from the base of the V $\phi$ ring Plateau slope at Site 343 . These were succeeded by deposition, over the whole plateau area, of relatively chaotic and ill-sorted glacial marine sediments presumably derived via gravity currents and floating ice from the adjacent continental margin, but including also thin streaks of nannofossil ooze marking periods of climatic amelioration.

Evidence of volcanic activity is most prevalent in the upper early Eocene through the middle Oligocene, although ash layers are also recorded in the lower Miocene and Plio-Pleistocene. There is little evidence of volcanism in the middle Miocene.

\section{ACKNOWLEDGMENTS}

This synthesis relies heavily upon work at sea undertaken on a cooperative basis by all Leg 38 participants. I thank them, especially sedimentologists T.H. Nilsen, D.A. Warnke, and S.M. White, for their contribution, both in the laboratory and in subsequent discussions. I am grateful to M. Talwani for making available reflection profiles shot by R.V. Vema, which were used in the construction of Figures 10 and 11, and to R. Walls and F. Jones for their help in heavy mineral and $\mathrm{X}$-ray diffraction analyses, respectively. R.E. Chapman, O. Eldholm, and I. Price were good enough to critically review the manuscript at very short notice. This paper is published with the permission of the British Petroleum Co. Ltd.

\section{REFERENCES}

Bjørklund, K. and Kellogg, D., 1972. Five new Eocene radiolarian species from the Norwegian Sea: Micropaleontology, v. 18 , p. 386-396.

Chapman, R.E. 1973. Petroleum geology: A concise study: Amsterdam (Elsevier).

1974. Clay diapirism and overthrust faulting: Geol. Soc. Am. Bull., v. 85, p. 1597-1602.

Eldholm, O. and Windisch, C.C., 1974. Sediment distribution in the Norwegian-Greenland Sea: Geol. Soc. Am. Bull., v. 85 , p. 1661-1676.

Hinz, K., 1972. Der Krustenaufbau des Norwegischen Kontinentalrandes (Voring Plateau) und der Norwegischen Tiefsee zwischen $66^{\circ}$ and $68^{\circ} \mathrm{N}$ nach seismischen Untersuchungen: "Meteor" Forschung., no. 10, p. 1-16.

Saito, T., Burckle, L.H., and Horn, D.R., 1967. Paleocene core from the Norwegian Basin: Nature, v. 216, p. $357-$ 359.

Talwani, M. and Eldholm, O., 1972. The continental margin off Norway: A geophysical study: Geol. Soc. Am. Bull., v. 83 , p. $3575-3606$.

Sea , in press. Evolution of the Norwegian-Greenland 